\title{
WestVirginiaUniversity
}

THE RESEARCH REPOSITORY @ WVU

Graduate Theses, Dissertations, and Problem Reports

2019

\section{Cognitive and Affective Influences on Decision-Making Strategies and Outcomes}

\author{
Michaela S. Reardon \\ msr0021@mix.wvu.edu
}

Follow this and additional works at: https://researchrepository.wvu.edu/etd

Part of the Psychology Commons

\section{Recommended Citation}

Reardon, Michaela S., "Cognitive and Affective Influences on Decision-Making Strategies and Outcomes" (2019). Graduate Theses, Dissertations, and Problem Reports. 4059.

https://researchrepository.wvu.edu/etd/4059

This Thesis is protected by copyright and/or related rights. It has been brought to you by the The Research Repository @ WVU with permission from the rights-holder(s). You are free to use this Thesis in any way that is permitted by the copyright and related rights legislation that applies to your use. For other uses you must obtain permission from the rights-holder(s) directly, unless additional rights are indicated by a Creative Commons license in the record and/ or on the work itself. This Thesis has been accepted for inclusion in WVU Graduate Theses, Dissertations, and Problem Reports collection by an authorized administrator of The Research Repository @ WVU. For more information, please contact researchrepository@mail.wvu.edu. 
Cognitive and Affective Influences on Decision-Making Strategies and Outcomes

Michaela S. Reardon, M.A.

Thesis submitted to the

Eberly College of Arts and Sciences

at West Virginia University

in partial fulfillment of the requirements for the degree of

Master of Science in

Psychology

Julie Hicks Patrick, Ph.D., Chair

Constance Toffle, Ph.D.

Elisa Krackow, Ph.D.

Department of Psychology

Morgantown, West Virginia

2019

Keywords: decision-making, age differences, cognition, executive functioning, affect

Copyright 2019 Michaela S. Reardon 


\begin{abstract}
Cognitive and Affective Influences on Decision-Making Strategies and Outcomes
\end{abstract}

\title{
Michaela S. Reardon
}

This study examines how factors such as emotion and planning abilities, determine decisionmaking strategies and outcomes. Consumer-based decision tasks are one way for researchers to measure the decision-making process and outcomes of individuals, while bringing an element of reality to the task through the utilization of decisions about everyday items that someone might purchase (e.g., a car, apartment, etc.). Using these types of tasks, researchers can measure the quality of a decision (e.g., did the participant come up with the best solution?), as well as the decision or search strategy. Previous research shows that cognitive factors are important when individuals make decisions (Engle, 2018). Emotional components are also important to consider when addressing decision making in adulthood. Older adults have a better memory for emotionladen content compared to younger adults (Yoon et al., 2009). Older adults also tend to display a bias toward positive information when making decisions (Carstensen et al., 1999). The current study uses emotional variables such as decision importance and task difficulty, as well as measures of cognitive functioning, such as the digit symbol substitution task, to predict decision making quality and strategies in a consumer-based task. While previous research shows that cognitive abilities (Engle, 2018; Patrick et al., 2013) and affective components (Carstensen et al., 1999) are both important for predicting decision-making outcomes, the research regarding affective components is less well established. Results found that those who relied on a particular search strategy were more than twice as likely $(\mathrm{OR}=2.34)$ to be classified as making a good decision in choosing a home. Results from this study have implications for alternate routes of intervention in the decision-making process. 
Table of Contents

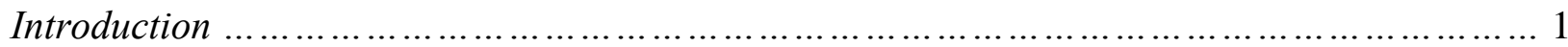

A Framework for Aging, Cognition, and Decision-Making …................................ 1

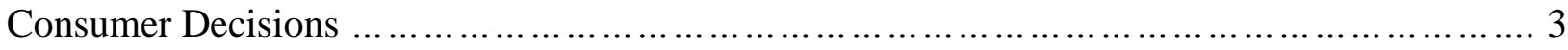

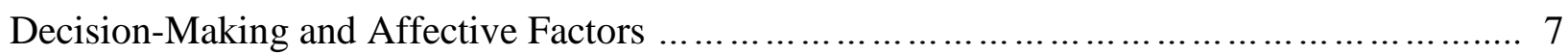

Individual Difference Factors and Decision-Making as a Function of Cognition and Affect ...... 9

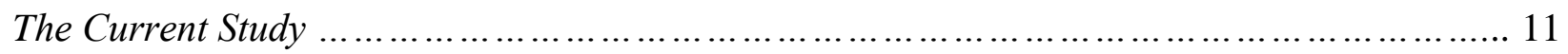

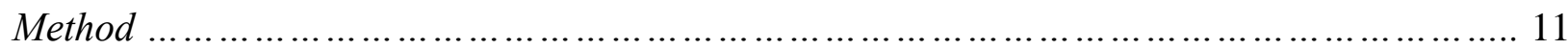

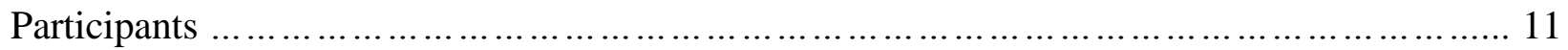

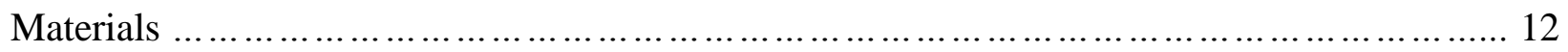

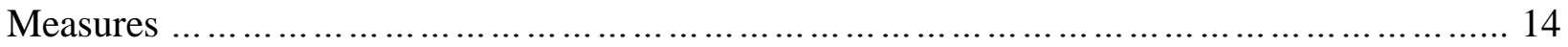

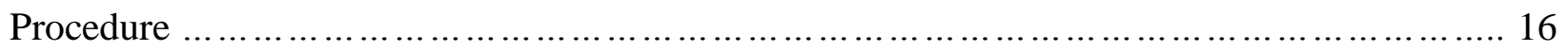

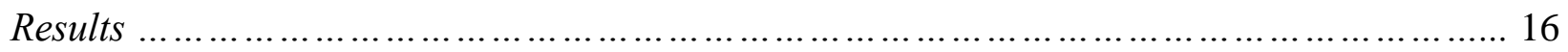

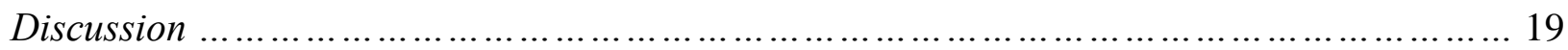

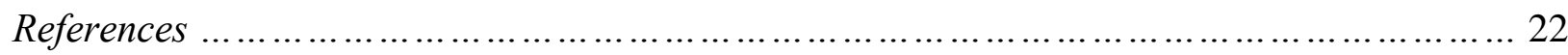

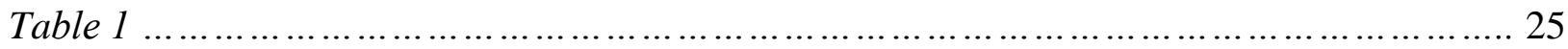

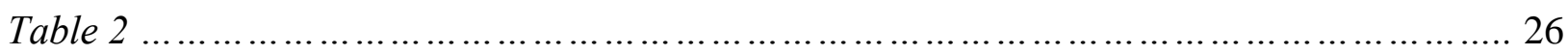

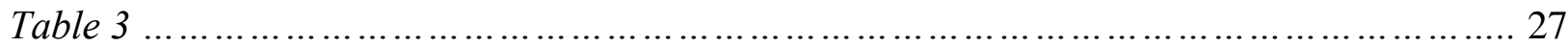

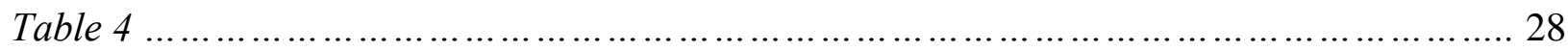

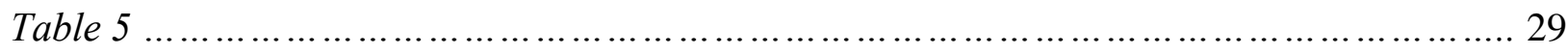

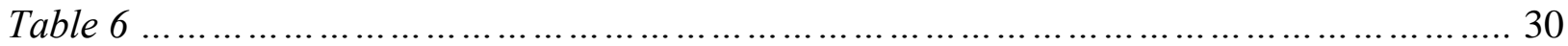

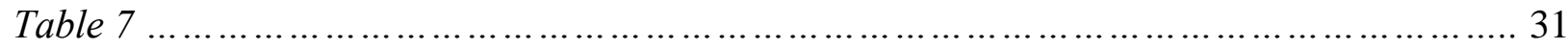

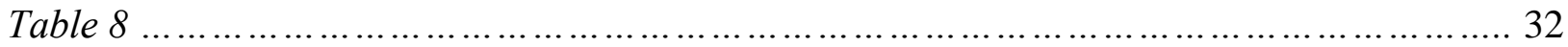




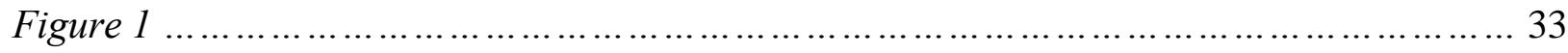

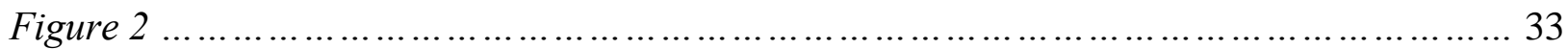

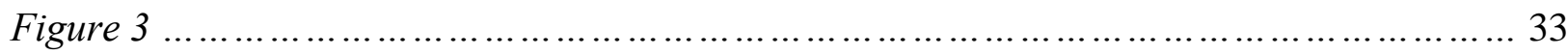

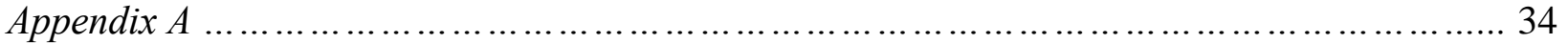

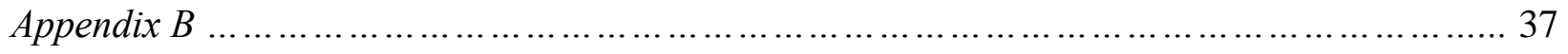


Previous research has found a link between cognitive factors and decisional strategies and outcomes (Patrick, Steele, \& Spencer, 2013). Affective factors have also been shown to influence both strategies (Isen \& Means, 1983) and outcomes (Forgas, 1989; von Helversen \& Mata, 2012); however, the research on affective factors is less established. The aim of this paper is to further the research on the influence of cognitive and affective factors on decisional outcomes and strategies. First, the link between cognition and decision-making will be established, followed by a review of the use of consumer-based decision matrices in research. Additionally, research on affective components of decision making, as well as individual difference factors will be addressed.

\section{A Framework for Aging, Cognition, and Decision-Making}

Cognition is a multidimensional construct that incorporates activities such as thinking, perceiving, remembering, knowledge acquisition, and even understanding language (Ginsburg \& Koslowski, 1976). Two important components of cognition are executive function and reaction time. Reaction time reflects how quickly an individual is able to respond to a stimulus. Executive functioning involves an individual's ability to set goals, plan, switch attention, and adjust their behavior accordingly (Salthouse, 2009). As people age, a decline is often noticed in some mental abilities, such as those related to executive functioning, memory, and processing speed (Hartshorne \& Germine, 2015). Processing speed is an ability that peaks in young adulthood and then begins to decline after the 20s (Hartshorne \& Germine, 2015); however, despite some of these losses, there are ways that adults cope with some of the age-related changes in order to compensate (Salthouse, 2009). Engle (2018) discusses working memory and fluid intelligence in relation to individuals' ability to perform complex, real-world tasks. Research shows that higherorder cognitive processes (e.g., executive functioning) and more basic cognitive abilities (e.g., 
reaction time) are needed to control attentional resources in order to complete complex tasks (Engle, 2018). Because older adults are sometimes unable to inhibit extra information (an aspect of executive functioning), they often have fewer working memory resources to devote to a task at hand (Hartshorne \& Germine, 2015). As adults age, it becomes more difficult to selectively attend to stimuli, but age-related declines are not uniform across all older adults. There are individual differences (Salthouse, 2009). While the influence of aging will not be tested in this study, it is important to note that there is a connection between cognitive processing abilities and decision-making strategies and outcomes (for another theory on cognitive components that underlie decision-making see Reyna \& Brainerd (2011)).

Experience and other knowledge-related abilities can counteract some of the attentional declines that are characteristic of aging and may explain some of the individual differences in cognitive performance. Research on decision-making suggests that there is a role for expertise or experience in determining both strategies used and decisional outcomes (Patrick et al., 2013; Patrick \& Strough, 2004; Yoon et al., 2009). Yoon and colleagues (2009) have suggested that older adults use less information when making a decision in a task with which the adult has experience because they are able to draw on previous search strategies in order to make a decision. This experience and knowledge that helps individuals in later problem-solving tasks may compensate for some losses in other cognitive skills. Repeated exposure to similar problems may also lead to more automatic responses. This reduces the cognitive demands placed on an individual which may result in fewer decision-making strategies used by older adults. While experience does not assure that a good decision will result, research suggests that experience may help (Patrick \& Strough, 2004). Other research suggests that task complexity is minimized when adults have experience, therefore they are able to lead a more focused search during a task 
of decision making (Queen, Hess, Ennis, Dowd, \& Gruhn, 2012). While the literature suggests there might be some age-related changes, experience, expertise (Patrick \& Strough, 2004), and cognitive abilities (Engle, 2018) affect decision-making strategies.

\section{Consumer Decisions}

Decision making is an important task in everyday life; adults make financial decisions, health decisions (Finucane, Mertz, Slovic, \& Schmidt, 2005), and decisions as consumers, such as what car to buy (Mather, Knight, \& McCaffrey, 2005; Patrick et al., 2013; Queen et al., 2012). There are various ways to appraise decision-making outcomes. For example, researchers may examine individuals' preferences in a decision task, such as "Which item do you prefer?" (Strough et al., 2015). Early research on decision outcomes by Forgas (1989) examined the information participants used to select a research partner by having the participants classify the information in hypothetical personnel files as important, not important, or not useful in their decision-making process.

Von Helversen and Mata (2012) used another method, a sequential decision-making task, that asked participants to view multiple different consumer products and find the best deal for each one. For each item, participants viewed up to 40 advertisements and had to make a decision when they came across what they believed would be the best decision (cheapest option/best deal). Participants could not re-view an advertisement once they passed up the option; they had to pick the next best one. The total number of advertisements viewed was recorded for each participant.

Another way to examine decision making is through the use of consumer-based decisions. Consumer-based decisions ask individuals to make a selection of a product (e.g., a car) for themselves (Mather et al., 2005; Queen et al., 2012) or others (Patrick et al., 2013), given a 
set of criteria such as lifestyle, budget, etc. That is, they take into account the person and the contextual factors involved in the decision. Consumer-based tasks also bring an element of reality to a task because they involve making decisions about everyday items that someone might purchase (e.g., a car, apartment, etc.). Thus, the objects are likely to be familiar to most individuals (e.g., most people would have purchased or rented a home or car). Additionally, the item features are reflective of reality, so an individual with more experience in a given content domain might not need to view all pieces of information available.

It is possible to evaluate the decision an individual makes in comparison to an expert group in order to survey the decision quality (Patrick et al., 2013). Because consumer-based tasks take into account a hypothetical individual's need, individuals' selections are determined to be correct or incorrect based on whether or not they matched expert decision rankings (Patrick et al., 2013). In the standard decision-making task, materials are developed to reflect those found outside the lab. A panel of experts from each domain (car and home industry) rank the "best choice" given the vignette. Then participants are asked to select the best choice and agreement between the experts and participants is calculated. By combining the knowledge of the expert outcome with the matrix format, each piece of information can be evaluated for whether it is relevant or important for the "best" answer (Patrick et al., 2013; Queen et al., 2012). Relevant pieces of information are determined by experts using the information given in a vignette that describes the individual's lifestyle, budget, etc. The proportion of relevant information a participant uses is determined by how many relevant pieces are viewed out of the total number of relevant pieces as established by the experts (Patrick et al., 2013); if there were eight pieces of relevant information and the participant viewed four of those, their proportion would be .50 . Researchers can also calculate a correlation between the participant rated importance of an 
attribute dimension (e.g., safety) and the number of times cells on that attribute were opened (Queen et al., 2012).

In addition to its increased ecological validity and ability to assess decision quality, expertly-developed materials allow the researcher to evaluate what information was used and evaluate the strategic search process involved in making a decision. Information search strategies have focused on how much information a person uses, how long they take to consider the choices, and how they combine information to make a decision (Parker, Bruine de Bruin, \& Fischhoff et al., 2007; Patrick et al., 2013; Queen et al., 2012). Building on work by Johnson (1990), Queen and colleagues (2012) used a matrix-decision task to look at the time spent on the entire search, the average time a participant viewed a cell within the matrix, the proportion of cells opened at least one time, and the number of times a cell was opened after the first viewing.

Alternative-based searches are exhaustive; each feature is evaluated and weighed for each alternative before a decision is made (Mata, von Helversen, \& Rieskamp, 2010; Patrick et al., 2013). For example, an individual might assess every quality about each car offered before making a purchase. Simpler strategic search processes involve a feature-based comparison; this has often been referred to as a non-compensatory search strategy. Feature-based comparisons are more efficient and are less cognitively taxing in that individuals focus on just a few alternatives (e.g., car models) that they believe are high or suitable in value on a chosen feature (e.g., safety rating or fuel efficiency), rather than taking all of the information into account (Mata et al., 2010; Patrick et al., 2013).

Patrick and colleagues (2013) used a ratio of repetition to determine if participants used a non-compensatory search strategy. The ratio of repetition examines the number of times a participant opens cells within a column and row. If a participant searched a column of features to 
look for an alternative on one particular feature (e.g., different houses based on the feature of location), they would have a high ratio of repetition for features. This means the participant would have repeatedly opened the same column several times and the number of times that column was examined would be recorded. This is indicative of a non-compensatory search strategy (Patrick et al., 2013). Alternatively, if a participant wants to view all information for one particular home, they would repeatedly look along the same row (viewing price, location, etc.). This would give the participant a high ratio of repetition for alternatives, indicative of a compensatory strategy. In consumer-based decision tasks, information is presented in a matrix so that researchers can evaluate whether participants gather information moving from feature to feature (comparing different choices on a single, important feature) or from alternative to alternative (gathering all of the information for a specific alternative before moving to the next alternative; Patrick et al., 2013; Queen et al., 2012).

Alternative-based comparisons are consistent with maximizing strategies. Individuals who rely on maximizing strategies tend to look at all of the information available before making decisions; these individuals also have been shown to have a higher need or liking for cognitively demanding tasks (Parker et al., 2007; Queen et al, 2012). Maximizers also are more likely to question their decision choices. The notion that participants who engage in maximizing strategies question their decisions more is another possible explanation for why these individuals engage in alternative-based searches; they cannot determine what information is most important to them in a purchasing decision (Parker et al., 2007). Satisficing is consistent with feature-based searches. Participants who engage in satisficing do not necessarily find the "best" option or the option most consistent with their preferences in attribute dimension, but they pick an option that is 
"good enough" to meet the needs of the individual for whom they are making a decision (Parker et al., 2007; Queen et al., 2012).

\section{Decision-Making and Affective Factors}

When older adults have a limited time perspective, they prefer emotion-related goals, in contrast to younger adults, who focus on knowledge gaining goals (Carstensen, Isaacowitz, \& Charles, 1999). Older adults also have a better memory for emotion-laden content rather than non-emotionally charged content. Age related decreases in cognitive resources may result in an increased dependence upon emotional strategies in decision making. For example, older adults may quickly eliminate options that they find to be negative or associated with a negative memory (Yoon et al., 2009). In one study older adults adopted a feature-based comparison and were more likely to pay attention to positive features of cars and focus less on negative features of cars (Mather et al., 2005). Younger adults did not display this same bias toward positive features. The results of this study highlight Carstensen's (1999) socioemotional selectivity theory which states that as adults age, they attempt to maximize social and emotional gains and minimize social and emotional losses because they realize that time is limited. This limited time perspective often results in a bias toward positive information and a focus is placed on people and events that individuals find emotionally meaningful and important (Carstensen, et al., 1999).

Affect has also been shown to play a role in search strategy (Isen \& Means, 1983;

Schwarz, 2000) and outcomes (Forgas, 1989; von Helversen \& Mata, 2012). Previous research shows that positive affect specifically is related to the use of existing knowledge and a top-down processing strategy in which less attention is paid to details. Conversely, negative affect has been linked with bottom-up processing and more attention to details in a task at hand. Search strategies involving a focused search examining one feature at a time is also more common with 
negative affect (Schwarz, 2000). Studies by Isen and Means (1983) and Forgas (1989) found that positive affect elicited faster decisions which is consistent with Schwarz's (2000) finding that individuals higher in positive affect use less exhaustive search processes than those higher in negative affect. Forgas (1989) used an analysis of variance to examine differences in search process between happy and sad participants. Happy participants reached a decision faster and in fewer steps than did sad participants. Isen and Means (1983) also found that those with higher positive affect were less likely to recheck older information that they had previously examined, quickly reducing the number of alternatives to search through on a consumer-based task regarding a fictional vehicle purchase.

The literature regarding affect has mainly been focused on the valence, whether the overall affective state of the participant is positive or negative. This is important when examining mood-congruent decisions where individuals are more likely to make an appraisal about a decision that is positive if they have or are induced to feel positive affect (Lerner \& Keltner, 2000). Lerner and Keltner (2000) found support for the appraisal-tendency hypothesis which states that not all emotions with a similar valence will have the same impact on judgements and decisions because they have different appraisal themes. For example, anger and fear are similar in that they are negative emotions; however, fear has components of uncertainty and external control whereas anger is generally associated with having a greater sense of certainty and internal control over situations (Lerner \& Keltner, 2000). While Lerner \& Keltner tried to expand the research using more specific positive and negative affective states, other aspects of affect such as importance or meaningfulness of a decision have yet to be explored. 


\section{Individual Difference Factors and Decision-Making as a Function of Cognition and Affect}

Numerous studies have examined decision-making strategies as they relate to differences among younger and older adults; however, results from these studies reveal conflicting evidence (Mata, et al., 2010; Patrick et al., 2013; Queen et al., 2012). Some research shows that search strategies differ by age when adults analyze information. Younger adults tend to make decisions after analyzing all information on the topic at hand in order to make the best possible decision; they are more likely to use an alternative based strategy (Mata et al., 2010). These alternativebased search strategies (also referred to as compensatory search strategies) are cognitively demanding since they require that all information made available to the consumer is processed and evaluated (Mata et al., 2010; Patrick et al., 2013). Older adults have been observed to view fewer pieces of information and focus only on features that they deem to be important or relevant when making a decision; they are more likely to use feature-based search strategies (also referred to as non-compensatory search strategies; Mata et al., 2010).

Von Helversen and Mata (2012) found similar results examining sequential decisionmaking with adults. Sequential decision-making requires that participants view ads for several of the same items, only differing in price. The object of the task is to not conclude the search too early or too late in order to obtain the best deal on a product (products were ranked in terms of the best possible deal through the worst possible deal). Their results showed that older adults selected offers that were ranked about two places below younger adults, and that a higher positive affect was related to decreased performance on the sequential decision-making task, less search in both age groups, and a lower threshold for accepting an offer (von Helversen \& Mata, 2012). While the research shows that sometimes quickly narrowing down a search works against 
and individual, those with experience and expertise in a given area can also narrow their search options fairly quickly and make a good decision (Queen et al., 2012).

Other studies have found minimal or no differences in decision making strategies among different age groups. Queen and colleagues (2012) used discriminant analyses to determine important participant characteristics that were associated with decision-making strategy. They found that a non-compensatory search strategy was more common among those with higher education, increased physical health and ability, and individuals who place a stronger importance on attributes. Compensatory strategies were also more common among participants who had a preference for thinking and being challenged. A strategy where all information is viewed and working memory is tested fits with those abilities and preferences. Yoon and colleagues (2009) note that age is important because many cognitive resources change as one ages; however, research is not always consistent about what constitutes old age. They also consider that it may not be age that is important, but functional ability of the individual completing the task.

There are other individual difference factors that influence cognitive ability and decision making outcomes. For example, health status decreases as individuals age and it is closely tied to cognition (Yoon et al., 2009). As people age, there are decreases in both sensory and physiological functioning. These decreases are dependent upon other factors such as lifestyle and medical conditions (Yoon et al., 2009). Individual differences such as socioeconomic status (SES) and education are also important factors in decision making. A compensatory strategy has been found to be more common among adults with lower SES and those with less education (Yoon et al., 2009). Non-compensatory strategies consistent with satisficing have been found to be associated with higher education and those in better health (Queen et al., 2012). 


\section{The Current Study}

The current study used existing data to examine decision making processes in adults.

Previous research shows that cognitive abilities, such as reaction time and executive functioning, are important for predicting decision-making strategies and outcomes (Engle, 2018, Patrick et al., 2013). Research has also shown that affective components matter in decision-making processes (Carstensen et al., 1999); however, this area of research less well established. The aim of the current study is to add to our understanding of cognitive and affective components and their roles in decision-making strategies and outcomes.

Hypothesis One: Executive function and reaction time will account for a significant amount of variance in decision quality.

Hypothesis Two: Affective components will account for a significant amount of variance in decision-making strategies and outcomes.

Research Question One: Does affect or cognition best account for differences in strategy and quality of decision?

\section{Method}

\section{Participants}

Data for this study came from the larger ABCD study (Patrick \& Gentzler); this health coaching study involved a pre-screen and four in-person data collection sessions. Decisionmaking data for the current study were gathered during the second and third in-person sessions and prescreen data were used for providing information on an affective component. The prescreen involved more than 1500 adults, although only 96 were invited to complete the in-person portion. Of those 96 adults, only a subset $(n=60)$ completed the decision tasks; 56 adults ages 18 through 72 had completed data and were included in final analyses ( 75 percent female). A 
power analysis, implemented in G Power (Faul, Erdfelder, Buchner, \& Lang, 2009) suggested that $\mathrm{N}=53$ would provide sufficient power $(\lambda=.80)$ to detect a large to medium-sized effect $\left(\mathrm{f}^{2}\right.$ $=.25$ ) with three to four predictors in a multiple regression.

\section{Materials}

Information Matrices. An 8 x 7 matrix (Patrick et al., 2013) was used to display the alternatives (i.e., different car types or houses) and features of those alternatives (e.g., safety ratings). Matrices were based on actual products available in the environment, similar to the information found in Consumer Reports. This added to the ecological validity of the task, enabling participants to use their existing expertise. The features for cars included price, style, appearance, safety, reliability, fuel, equipment, and performance. The housing features include rent, size, locale, medical services, non-medical services, social, safety, and rules/options.

Participants viewed matrices on the computer and were able to view one cell of information at a time, in any order. Participants were not allowed to write down any information, but could look back through information as many times as they wished before making a decision. Time spent on the task was recorded in milliseconds.

Vignettes. Participants were asked to make a purchase decision for themselves and for hypothetical individuals described in a vignette. Participants engaged in two initial practice scenarios where they chose a candy bar and a suit for themselves. This helped to acquaint them with the program used for the study. After the two practice scenarios, the participants received the vignettes for either the car or home decisions domains, depending on the week. At week 1 participants were asked to make decisions about purchasing a car, and at week 2 they made decisions about purchasing a home. The vignettes and their matching matrices were always counterbalanced across participants within domain. The vignettes describe the individuals' 
lifestyle and financial situation, thus some the needs of these individuals were implied, while others were clearly stated. Participants viewed two vignettes for purchasing a car and two for selecting a home. Participants also engaged in a self-condition where they chose a car or home for themselves before selecting one for others in each decision domain. Thus, participants made three decisions in each domain during the study.

The two vignettes for cars focused on a hypothetical single individual and a couple. The single individual, Chris, was a college student that had commuting needs to and from school and work. The couple, Larry and Sue, were professionals that regularly entertained clients. The two vignettes for homes focused on two hypothetical older women. One of the older women, Anna, was an older adult in poor health who wished to have more community engagement. Betty was the second older adult in the home vignette. She was healthy, wished for more engagement with peers, and had a good income (Patrick et al., 2013).

Total time on task for cars $(M=147.31, \mathrm{SD}=65.19)$ and homes $(M=182.47, \mathrm{SD}=$ $87.51)$, and total number of pieces of information used for cars $(M=20.45, \mathrm{SD}=11.41)$ and homes $(M=23.26, \mathrm{SD}=14.23)$ were assessed using the vignettes and matrices. Information on overall alternative-based and feature-based strategies were assessed. Alternative-based and feature-based strategies were assessed for each decision that was made by counting the number of times the row (alternatives) or column (features) was opened consecutively by a participant. An overall domain-specific score was computed for each participant by averaging their ratio of repetition for choices $A$ and $B$ in each of the two domains. A high ratio of repetition for alternatives was indicative of a compensatory search, whereas a high ratio of repetition for features indicated a non-compensatory search. Strategy could not be assessed for the practice 
conditions because the matrices were not large enough to calculate a ratio of repetition for participants.

Quality of Decisions. The quality of decisions was assessed for both car and home decision domains. Each domain was broken down into whether or not participants made at least one good decision when completing the matrices. In scenario A for the car decision, 21.90 percent made a good decision, while in scenario B, 40.60 percent made a good decision. Combining across scenarios for the car decision revealed that 50 percent of individuals made at least one good decision.

Scenario A for the housing domain showed that only seven percent of individuals made a good decision, and in scenario B, 55.60 percent of individuals made a good decision. Combining across scenarios in the housing domain, 62.20 percent of participants made at least one good decision.

\section{Affective Measures}

At the pre-screen, individuals were asked a series of questions, including those about a place to live and automobile purchases. Participants indicated how important the decision to purchase a car or house was $(1=$ not very important; $5=$ very important $)$. Participants were also asked about how emotionally meaningful the decision is to buy a car or house $(1=$ not very meaningful; $5=$. Very meaningful). Participants indicated how intellectually difficult it is to make a decision about purchasing a home or car $(1=$ not very intellectually difficult; $5=$ very intellectually difficult). Finally, participants were asked how recently they had purchased a car $(M=3.41, \mathrm{SD}=1.39)$ or home $(M=3.35, \mathrm{SD}=1.32)$ for themselves $(1=$ "never," $2=$ "within the past year," $3=$ " 1 to 2 years ago," $4=$ " 2 to 5 years ago," $5=$ "more than 5 years ago"). 
Affective Scales. For each domain, the ratings for meaningfulness and importance were combined to form a single scale. Affective scales for Cars had a mean of $6.36(\mathrm{SD}=2.22$, alpha $=.76)$. For Homes, the affective scale had a mean of $9.62(\mathrm{SD}=.8$, alpha $=.63)$. Thus, indicating decent internal reliability for scales containing only two items. Meaningfulness and importance were chosen for the affective component because these factors relate to Carstensen and colleagues' (1999) Socioemotional Selectivity Theory which highlights differences in maximizing social and emotional gains and minimizing these losses. For example, older individuals will spend more time with individuals with whom they have more meaningful relationships and whom they find more important to them because of the limited time perspective.

\section{Cognitive Measures}

Digit- Substitution. The digit-symbol substitution task is a measure of executive function and was administered electronically. For this test the participant used a list of nine digitsymbol pairs to list the corresponding symbol next to a list of digits in an allotted time-span. The average response rate for each participant was calculated in milliseconds $(M=1862.36, S D=$ 340.87) and participants repeated this task until they reached 100 percent accuracy. Participants were given a trial period with feedback to start, and then progressed to the experimental condition where no feedback was given (Mueller \& Piper, 2014).

Four Choice Reaction Time Test. This is a test of reaction time where an individual had to detect a stimulus in one of four quadrants on a computer screen. The participant had to press a button to indicate where the stimuli is both quickly and accurately, thus measuring reaction time in milliseconds $(M=688.89, S D=295.66)$ among participants (Mueller $\&$ Piper, 2014). 


\section{Procedure}

Participants completed informed written consent before beginning participation in the study. Participants then took some prescreen measures for this study, such as global cognition and personality measures. Participants were then invited to complete the in-person portion of this study that included the cognitive measures, digit-symbol substitution, a measure of executive function, and a four-choice reaction time test. Participants also made importance ratings on features of cars and houses prior to beginning the study.

The cognitive processing measures and affective measures were obtained at Baseline (Week 0), the automobile decisions were made at Week 1, and Housing decisions were made at Week 2. Before completing the decision matrices, participants completed a guided practice decision using a 2 by 3 matrix for candy bars and a 4 by 4 matrix for a suit of clothing for a female lawyer. This was followed by the first 8 by 7 domain matrix (automobile, housing) for which a person chose an alternative for themselves. Each participant then made a decision about a purchase for two other individuals following the choice made for themselves. Vignettes were provided in order to aid the participant in making a selection for the other individuals. The vignettes and matrices are presented in Appendix A. In each vignette, the hypothetical needs and resources for each fictional person/couple were addressed. Vignettes were written so that participants all had the objective to meet the hypothetical characters' needs (Patrick et al., 2013).

\section{Results}

Two affective scales, one for houses and one for cars, were created using the emotional meaningfulness and importance items for each respective domain. These scales were used in subsequent analyses (see materials for scale reliability). Decision quality was also assessed for 
each domain. Individuals were classified as a good decision-maker in each domain if they made at least one of the "good decisions" (expert determined) out of the two possible decisions.

Bivariate correlations were examined (Table 3) between the decision quality variables, the digit-symbol substitution task, the affective scales, and the alternative and feature-based strategies for each decision domain. Both Pearson's $r$ and Spearman's $\rho$ (rho) correlation coefficients were calculated for variables in order to appropriately assess the ordinal nature of some of the scales. Car decision quality was not significantly associated with any of the other variables. House quality was only significantly negatively associated with the car affective scale $(\rho=-.43, p<.01)$. The affective scale for housing decisions was significantly negatively associated with using an alternative based search strategy $(\rho=-.30, p<.05)$. Additionally, the use of an alternative-based strategy in the car domain was positively related to the use of an alternative-based strategy in the housing domain $(r=.45, p<.05)$. Similarly, the use of a feature-based strategy in the car domain was significantly related to the use of a feature-based strategy in the housing domain $(r=.45, p<.05)$. Correlation analyses also revealed that the average number of pieces of information used and the average total time it took participants to make a decision were not related to strategy or decision quality.

Correlations were also used to determine if the recency of making a decision about purchasing a car or home was related to decision strategy or quality. The recency of purchasing a car was not related to either strategy (feature versus alternative) or the quality of the decision. Similarly, the recency of purchasing a home was not related to either strategy or decision quality on the decision matrix.

Correlations including demographic information and other study variables revealed that age was associated with the digit-symbol task $(r=.58, p<.05)$. Age was also associated with 
the other cognitive variable, the four-choice reaction time test $(r=.57, p<.05)$. The two cognitive variables were moderately correlated $(r=.59, p<.05)$; however, due to the lower number of individuals that participated in the four-choice reaction time test, the cognitive variable included in subsequent regression analyses was the digit-symbol task. Additional correlations were examined between all variables measured (see Table 3).

\section{Cars}

Two logistic regressions, one for each decision domain, were conducted in order to best analyze the data collected and address the proposed hypotheses because of the dichotomous dependent variable. A logistic regression was conducted predicting car decision quality (see figure 1) using digit-symbol time, the affective scale for cars, and an alternative search strategy. With all three predictors entered, the equation was not significant, $x^{2}(d f=3)=3.69, p=.30$. The pseudo $\mathrm{R}^{2}$ measures were low for this analysis, Cox \& Snell $=.12$, Nagelkerke $=.16$. For the car buying decision, 66.70 percent of individuals were classified correctly, with 75 percent classified as making a good decision. Examination of the coefficients did not reveal any predictors as increasing the odds for correct classification.

A mediation analysis was conducted to examine direct and indirect effects of affect on car decision quality with an alternative-based strategy as a mediator. Neither the direct nor indirect pathways were significant for this model. The model was also examined using a featurebased strategy as the mediator, and again, neither the direct nor indirect effects were significant.

\section{Homes}

A logistic regression was conducted predicting home decision quality (see figure 2) using the digit symbol time, alternative search strategy, and the affective scale for the housing domain. With all three predictors entered in the same step, the equation was not significant, $x^{2}(\mathrm{df}=3)=$ 
3.06, $p=.38$. The pseudo $\mathrm{R}^{2}$ measures were also low, Cox $\&$ Snell $=.07$ and Nagelkerke $=.10$. Seventy percent of individuals were correctly classified as making a good decision, with 92.3 percent of the individuals making a good decision correctly classified. Although the model failed to reach significance and the beta weight for an alternative-based strategy was not significant (B $=.85$, Wald $=.21$, examination of the Odds Ratio showed that adults who relied an alternativebased strategy were more than twice as likely $(\mathrm{OR}=2.34)$ to be classified as making a good decision in choosing a home in the vignettes. Additionally, those who scored higher on the affective scale (importance and meaningfulness of domain specific decisions) were 2.16 times more likely to be classified as making a good decision $(\mathrm{B}=.77$, Wald $=1.91)$.

The relations between affect, decision strategy and decision quality for the housing domain was also assessed using a mediation model (see figure 3) with affect predicting decision quality through an alternative-based strategy. While the model as a whole did not produce any direct or indirect effects, there was a significant effect for affect predicting the use of an alternative-based strategy $(b=-.11, p=.04)$. When the feature-based strategy was entered into the same model (affect predicting decision quality), the path from affect to decision strategy was also significant $(\mathrm{b}=.09, p=.03)$.

\section{Discussion}

The main purpose of this study was to examine the decision-making process in a wide age range of adults. While research shows that both cognitive abilities (Engle, 2018; Patrick et al., 2013) and affective factors (Carstensen et al., 1999; Isen \& Means, 1983; von Helversen \& Mata, 2012) are important for decision-making processes, the research on affective factors was less well established and mainly focuses solely on valence (i.e., positive emotions versus negative emotions in decision-making). Hypothesis 1 stated that a cognitive measure of 
executive function (digit-symbol substitution test) would account for a significant amount of variance in decision quality. This hypothesis was tested for both the car and home domains through the use of logistic regression because of the dichotomous outcome variable, decision quality. The cognitive variables in the logistic regression equations for each domain were not significant predictors that increased classification for whether or not individuals made a good quality decision, thus, hypothesis one was not supported. The findings from this study are contradictory to the literature that has found cognitive processes to be an important factor related to complex tasks (Engle, 2018).

Hypothesis 2 stated that affective components would account for a significant amount of variance in decision-making strategies. This hypothesis was also tested using the logistic regression equation. The affective scale was not a predictor that increased the odds for correct classification in the car or home domains; however, the odds ratio in the logistic regression specific to the home domain showed that individuals who relied more heavily on an alternativebased strategy were more than twice as likely to make a good decision. Additionally, in the mediation model the indirect pathway from affect (the predictor) to alternative-based strategy (the mediator) was significant. This suggests that while hypothesis two was not supported, it does demonstrate that affect is related to an alternative-based decision-making strategy. The findings in this study are consistent with the research by von Helversen and Mata (2012) which also found that affect (positive) was predictive of search strategy, but measures of fluid cognitive abilities were not predictive of search strategy.

The research question that this study attempted to answer was, does affect or cognition best account for differences in strategy and quality of decision? Based on the logistic regressions for the home domain, as well as the mediation models, affect, but not cognition best accounts for 
differences in strategy and quality of decision. Again, this is consistent with some findings in the literature (von Helversen \& Mata, 2012); however, there is also literature that suggests each variable would be important.

Given that there is some conflicting evidence regarding the importance of affect and cognitive abilities in decision-making strategies and outcomes, future studies might attempt to use a different measure of cognitive abilities to capture executive function. Future studies should also analyze the vincentized ratio of repetition for both the feature and alternative strategies. This would allow for researchers to examine changes in search strategy throughout the decision tasks.

This study was limited in that it was a small sample of adults from one geographic area, meaning that these results may not generalize to the population at large. Additionally, there was not both car and home domain information for every single participant (more data on housing domain), so that may have influenced the results. Because of the small sample size, the mediation analyses that were conducted were also low-powered. To stabilize the beta weights, 5,000 bootstrapped samples were used. 


\section{References}

Carstensen, L. L., Isaacowitz, D. M., \& Charles, S. T. (1999). Taking time seriously: A theory of socioemotional selectivity. American Psychologist, 54(3), 165-181.

Engle, R.W. (2018). Working memory and executive attention: A revisit. Perspectives on Psychological Science, 13(2), 190-193.

Faul, F., Erdfelder, E., Buchner, A., \& Lang, A. (2009). Statistical power analyses using g*power 3.1: Tests for correlation and regression analyses. Behavior Research Methods, 41(4), 1149-1160.

Finucane, M. L., Mertz, C. K., Slovic, P., \& Schmidt, E. S. (2005). Task complexity and older adults' decision-making competence. Psychology and Aging, 20(1), 71-84.

Forgas, J. P. (1989). Mood effects on decision making strategies. Australian Journal of Psychology, 41(2), 197-214.

Ginsburg, H., \& Koslowski, B. (1976). Cognitive development. Annual Review of Psychology, 27(1), 29-61.

Hartshorne, J. K., \& Germine, L. T. (2015). When does cognitive functioning peak? The asynchronous rise and fall of different cognitive abilities across the lifespan. Psychological Science, 0956797614567339.

Isen, A. M., \& Means, B. (1983). The influences of positive affect on decision-making strategy. Social Cognition, 2(1), 18-31.

Johnson, M. M. S. (1990). Age differences in decision making: A process methodology for examining strategic information processing. Journals of Gerontology, 45(2), 75-78.

Lerner, J. S., \& Keltner, D. (2000). Beyond valence: Toward a model of emotion-specific influences on judgement and choice. Cognition and Emotion, 14(4), 473-493. 
Mata, R., von Helversen, B., \& Rieskamp, J. (2010). Learning to choose: Cognitive aging and strategy selection learning in decision making. Psychology and Aging, 25(2), 299-309.

Mather, M., Knight, M., \& McCaffrey, M. (2005). The allure of the alignable: Younger and older adults' false memories of choice features. Journal of Experimental Psychology: General, 134(1), 38-51.

Mueller, S. T., \& Piper, B. J. (2014). The psychology experiment building language (PEBL) and PEBL test battery, Journal of Neuroscience Methods, 222, 250-259.

Parker, A. M., Bruine de Bruin, W., Fischhoff, B. (2007). Maximizers versus satisficers: Decision-making styles, competence, and outcomes. Judgment and Decision Making, 2(6), 342-350.

Patrick, J. H., Steele, J. C., \& Spencer, S. M. (2013). Decision making processes and outcomes. Journal of Aging Research, 367208.

Patrick, J. H., \& Strough, J. (2004). Everyday problem solving: Experience, strategies, and behavioral intentions. Journal of Adult Development, 11, 9-18.

Queen, T. L., Hess, T. M., Ennis, G. E., Dowd, K., \& Gruhn, D. (2012). Information search and decision making: Effects of age and complexity on strategy use. Psychology and Aging, $27(4), 817-824$.

Reyna, V. F., \& Brainerd, C. J. (2011). Dual processes in decision making and developmental neuroscience: A fuzzy-trace model. Developmental Review, 31(2), 180-206.

Salthouse, T. A. (2009). Relations between age and cognitive functioning (ch. 1). In Salthouse, Timothy A. Major issues in cognitive aging (Chapter 1, pp. 3-34), Oxford University Press. 
Schwarz, N. (2000). Emotion, cognition, and decision making. Cognition and Emotion, 14(4), 433-440.

Strough, J., Bruine de Bruin, W., \& Peters, E. (2015). New perspectives for motivating better decisions in older adults. Frontiers in Psychology, 6, 783-793.

von Helversen, B., \& Mata, R. (2012). Losing a dime with a satisfied mind: Positive affect predicts less search in sequential decision making. Psychology and Aging, 27(4), 825839.

Yoon, C., Cole, C. A., \& Lee, M. P. (2009). Consumer decision making and aging: Current knowledge and future directions. Journal of Consumer Psychology, 19(1), 2-16. 
Table 1

Means and Standard Deviations for Scales, Cars, and Homes

\begin{tabular}{|c|c|c|c|c|c|}
\hline Variable & $\mathrm{N}$ & $\mathrm{M}$ & SD & Minimum & Maximum \\
\hline Age & 56 & 41.86 & 15.66 & 18.00 & 72.00 \\
\hline Quality Car & 56 & .41 & .71 & 0.00 & 2.00 \\
\hline Affect Car & 53 & 6.36 & 2.22 & 2.00 & 10.00 \\
\hline Features Car & 32 & .60 & .21 & .14 & .95 \\
\hline Alternate Car & 32 & .31 & .18 & .07 & .77 \\
\hline Total Time Car & 32 & 147.31 & 65.19 & 62.05 & 335.18 \\
\hline Pieces Info Car & 32 & 20.45 & 11.41 & 6.00 & 66.50 \\
\hline Quality House & 56 & .63 & .68 & 0.00 & 2.00 \\
\hline Affect House & 53 & 9.62 & .88 & 5.00 & 10.00 \\
\hline Features House & 45 & .54 & .17 & .07 & .87 \\
\hline Alternate House & 45 & .39 & .21 & .04 & 1.00 \\
\hline Total Time House & 45 & 182.47 & 87.51 & 48.67 & 510.59 \\
\hline Pieces Info House & 45 & 23.26 & 14.23 & 4.50 & 89.00 \\
\hline Four Choice & 47 & 688.89 & 295.66 & 360.48 & 1396.89 \\
\hline Letter Digit & 50 & 1862.36 & 340.87 & 1179.43 & 2890.33 \\
\hline Pieces info A Car & 31 & 20.10 & 13.71 & 0.00 & 76.00 \\
\hline Repeats A Car & 31 & .18 & .18 & 0.00 & .64 \\
\hline Time A Car & 32 & 142.75 & 81.73 & 2.25 & 366.35 \\
\hline Alternative A Car & 30 & .31 & .19 & 0.00 & .78 \\
\hline Feature A Car & 30 & .63 & .21 & .15 & 1.00 \\
\hline Pieces info B Car & 32 & 20.53 & 10.65 & 4.00 & 57.00 \\
\hline Repeats B Car & 32 & .19 & .16 & 0.00 & .57 \\
\hline Time B Car & 32 & 151.87 & 63.93 & 42.74 & 304.01 \\
\hline Alternative B Car & 32 & .31 & .21 & 0.00 & .79 \\
\hline Feature B Car & 32 & .57 & .25 & 0.00 & .89 \\
\hline Pieces info A House & 43 & 24.44 & 19.47 & 2.00 & 117.00 \\
\hline Repeats A House & 42 & .24 & .18 & 0.00 & .60 \\
\hline Time A House & 43 & 117.88 & 93.06 & 37.19 & 439.84 \\
\hline Alternative A House & 43 & .38 & .26 & 0.00 & 1.00 \\
\hline Feature A House & 43 & .56 & .23 & 0.00 & .90 \\
\hline Pieces info B House & 45 & 22.27 & 13.38 & 4.00 & 61.00 \\
\hline Repeats B House & 43 & .74 & 3.79 & 0.00 & 25.00 \\
\hline Time B House & 45 & 187.14 & 109.40 & 34.82 & 652.07 \\
\hline Alternative B House & 45 & .39 & .24 & 0.00 & 1.00 \\
\hline Feature B House & 45 & .52 & .23 & 0.00 & 1.00 \\
\hline
\end{tabular}

Note. Total time was measured in milliseconds. 
Table 2

Means and Standard Deviations of Affective Variables

\begin{tabular}{lccccc}
\hline \multicolumn{1}{c}{ Variable } & $\mathrm{N}$ & $\mathrm{M}$ & $\mathrm{SD}$ & Minimum & Maximum \\
\hline Importance House & 53 & 4.89 & .32 & 4.00 & 5.00 \\
Meaningfulness House & 53 & 4.74 & .65 & 1.00 & 5.00 \\
Difficulty House & 51 & 3.59 & 1.31 & 1.00 & 5.00 \\
Recency House & 51 & 3.41 & 1.39 & 1.00 & 5.00 \\
Importance Car & 53 & 3.43 & 1.17 & 1.00 & 5.00 \\
Meaningfulness Car & 53 & 2.92 & 1.30 & 1.00 & 5.00 \\
Difficulty Car & 51 & 3.16 & 1.22 & 1.00 & 5.00 \\
Recency Car & 51 & 3.35 & 1.32 & 1.00 & 5.00 \\
\hline
\end{tabular}


Table 3

Pearson Correlations - Part 1

\begin{tabular}{|c|c|c|c|c|c|c|c|c|c|c|c|}
\hline & \multirow{2}{*}{\multicolumn{3}{|c|}{$\#$}} & \multirow{2}{*}{\multicolumn{3}{|c|}{$\#$}} & \multicolumn{3}{|c|}{$\#$} & \multirow[b]{2}{*}{ Choice } & \multirow{3}{*}{$\begin{array}{c}\# \\
\text { Pieces } \\
\text { House }\end{array}$} \\
\hline & & & & & & & Choice & Pieces & Time & & \\
\hline & Choice & Pieces & Time & Choice & Pieces & Time & House & House & House & House & \\
\hline & Car A & Car A & Car A & Car B & Car B & Car B & $\mathrm{A}$ & A & $\mathrm{A}$ & $\mathrm{B}$ & B \\
\hline Choice Car A & 1 & 0.116 & -0.021 & 0.190 & 0.255 & 0.037 & 0.083 & -0.246 & -0.368 & 0.236 & 0.085 \\
\hline \# Pieces Car A & - & 1 & $.742^{* *}$ & -0.043 & $.769^{* *}$ & $.593^{* *}$ & 0.135 & $.486^{*}$ & 0.220 & $.619^{* *}$ & 0.386 \\
\hline Time Car A & - & - & 1 & -0.097 & $.376^{*}$ & $.596^{* *}$ & $.468^{*}$ & 0.172 & $.449^{*}$ & $.440^{*}$ & 0.309 \\
\hline Choice Car B & - & - & - & 1 & -0.036 & 0.094 & 0.183 & -0.324 & -0.169 & -0.189 & -0.067 \\
\hline \# Pieces Car B & 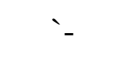 & - & - & - & 1 & $.738^{* *}$ & 0.101 & $.520^{* *}$ & 0.202 & $.671^{* *}$ & 0.367 \\
\hline Time Car B & - & - & - & - & - & 1 & 0.398 & 0.324 & $.474^{*}$ & $.553^{* *}$ & $.477^{*}$ \\
\hline Choice House A & - & - & - & - & - & - & 1 & -0.296 & -0.186 & $.337^{*}$ & -0.029 \\
\hline \# Pieces House A & - & - & - & - & - & - & - & 1 & $.644^{* *}$ & $.360^{*}$ & $.526^{* *}$ \\
\hline Time House A & - & - & - & - & - & - & - & - & 1 & 0.249 & $.435^{* *}$ \\
\hline Choice House B & - & - & - & - & - & - & - & - & - & 1 & $.393^{* *}$ \\
\hline \# Pieces House B & - & - & - & - & - & - & - & - & - & - & 1 \\
\hline Time House B & - & - & - & - & - & - & - & - & - & - & - \\
\hline Four Choice & - & - & - & - & - & - & - & - & - & - & - \\
\hline Letter Digit & - & - & - & - & - & - & - & - & - & - & - \\
\hline Live Importance & - & - & - & - & - & - & - & - & - & - & - \\
\hline Live Meaningful & - & - & - & - & - & - & - & - & - & - & - \\
\hline Live Difficulty & - & - & - & - & - & - & - & - & - & - & - \\
\hline Live Recency & - & - & - & - & - & - & - & - & - & - & - \\
\hline Car Importance & - & - & - & - & - & - & - & - & - & - & - \\
\hline Car Meaningful & - & - & - & - & - & - & - & - & - & - & - \\
\hline Car Difficulty & - & - & - & - & - & - & - & - & - & - & - \\
\hline Car Recency & - & - & - & - & - & - & - & - & - & - & - \\
\hline Age & - & - & - & - & - & - & - & - & - & - & - \\
\hline Sex & - & - & - & - & - & - & - & - & - & - & - \\
\hline Alternatives Car & - & - & - & - & - & - & - & - & - & - & - \\
\hline $\begin{array}{l}\text { Alternatives } \\
\text { House }\end{array}$ & - & - & - & - & - & - & - & - & - & - & - \\
\hline Features Car & - & - & - & - & - & - & - & - & - & - & - \\
\hline Features House & - & - & - & - & - & - & - & - & - & - & - \\
\hline Affect scale car & - & - & - & - & - & - & - & - & - & - & - \\
\hline $\begin{array}{l}\text { Affect scale } \\
\text { house }\end{array}$ & - & - & - & - & - & - & - & - & - & - & - \\
\hline Car Decision & - & - & - & - & - & - & - & - & - & - & - \\
\hline House Decision & - & - & - & - & - & - & - & - & - & - & - \\
\hline
\end{tabular}

$*$ significant at $p<.05$

$* *$ significant at $p<.01$ 
Table 4

Pearson Correlations - Part 2

\begin{tabular}{|c|c|c|c|c|c|c|c|c|c|c|c|}
\hline & $\begin{array}{l}\text { Time } \\
\text { House } \\
\text { B }\end{array}$ & $\begin{array}{l}\text { Four } \\
\text { Choice }\end{array}$ & $\begin{array}{l}\text { Letter } \\
\text { Digit }\end{array}$ & $\begin{array}{l}\text { Live } \\
\text { Import } \\
\text {-ance }\end{array}$ & $\begin{array}{l}\text { Live } \\
\text { Meani } \\
\text {-ngful }\end{array}$ & $\begin{array}{l}\text { Live } \\
\text { Diffic- } \\
\text { ulty }\end{array}$ & $\begin{array}{l}\text { Live } \\
\text { Recen- } \\
\text { cy }\end{array}$ & $\begin{array}{l}\text { Car } \\
\text { Import } \\
\text {-ance }\end{array}$ & $\begin{array}{l}\text { Car } \\
\text { Meani } \\
\text {-ngful }\end{array}$ & $\begin{array}{l}\text { Car } \\
\text { Diffic- } \\
\text { ulty }\end{array}$ & $\begin{array}{l}\text { Car } \\
\text { Recen- } \\
\text { cy }\end{array}$ \\
\hline Choice Car A & -0.087 & -0.210 & -0.155 & -0.233 & 0.010 & -0.201 & -0.153 & -0.061 & 0.223 & -0.035 & -0.150 \\
\hline \# Pieces Car A & 0.155 & -0.135 & -0.298 & -0.127 & -0.280 & -0.044 & -0.294 & $-.383^{*}$ & -0.182 & -0.053 & -0.198 \\
\hline Time Car A & $.595^{* *}$ & 0.236 & 0.017 & -0.033 & -0.119 & -0.028 & -0.039 & -0.301 & -0.163 & 0.107 & -0.142 \\
\hline Choice Car B & 0.080 & 0.077 & 0.107 & -0.130 & 0.098 & 0.006 & 0.231 & 0.008 & -0.070 & -0.141 & -0.130 \\
\hline \# Pieces Car B & 0.099 & -0.287 & $-.390^{*}$ & -0.035 & -0.088 & 0.153 & -0.200 & -0.158 & 0.056 & 0.040 & -0.195 \\
\hline Time Car B & $.604^{* *}$ & 0.126 & -0.129 & -0.007 & 0.007 & 0.063 & 0.105 & -0.076 & 0.009 & 0.301 & -0.158 \\
\hline Choice House A & 0.128 & 0.145 & 0.141 & 0.165 & 0.199 & -0.204 & 0.239 & -0.006 & -0.079 & 0.025 & -0.006 \\
\hline \# Pieces House A & 0.090 & -0.257 & $-.359^{*}$ & -0.204 & -0.290 & 0.108 & -0.280 & 0.016 & -0.018 & 0.163 & $-.380^{*}$ \\
\hline Time House A & $.514^{* *}$ & 0.138 & -0.003 & -0.202 & -0.252 & 0.060 & 0.132 & 0.055 & 0.100 & 0.134 & -0.110 \\
\hline Choice House B & 0.250 & -0.078 & -0.235 & 0.116 & 0.248 & -0.015 & 0.018 & 0.035 & 0.052 & 0.122 & -0.077 \\
\hline \# Pieces House B & $.609^{* *}$ & -0.215 & -0.206 & -0.016 & -0.226 & -0.068 & 0.011 & -0.018 & 0.073 & 0.191 & $-.443^{* *}$ \\
\hline Time House B & 1 & 0.172 & 0.196 & -0.062 & -0.020 & 0.051 & $.309^{*}$ & 0.020 & 0.084 & 0.286 & -0.159 \\
\hline Four Choice & - & 1 & $.591^{* *}$ & -0.077 & 0.084 & -0.138 & $.413^{* *}$ & 0.095 & 0.084 & -0.114 & 0.284 \\
\hline Letter Digit & - & - & 1 & -0.132 & 0.060 & -0.045 & 0.283 & 0.103 & $.288^{*}$ & -0.043 & 0.231 \\
\hline Live Importance & - & - & - & 1 & $.589^{* *}$ & $.305^{*}$ & 0.021 & 0.237 & 0.025 & 0.047 & $.284^{*}$ \\
\hline Live Meaningful & - & - & - & - & 1 & 0.257 & 0.146 & $.329^{*}$ & 0.180 & 0.103 & $.475^{* *}$ \\
\hline Live Difficulty & - & - & - & - & - & 1 & -0.081 & $.278^{*}$ & 0.123 & $.390^{* * *}$ & 0.235 \\
\hline Live Recency & - & - & - & - & - & - & 1 & $.296^{*}$ & 0.259 & 0.103 & 0.093 \\
\hline Car Importance & - & - & - & - & - & - & - & 1 & $.618^{* *}$ & $.589^{* *}$ & 0.020 \\
\hline Car Meaningful & - & - & - & - & - & - & - & - & 1 & $.475^{* *}$ & 0.024 \\
\hline Car Difficulty & - & - & - & - & - & - & - & - & - & 1 & -0.010 \\
\hline Car Recency & - & - & - & - & - & - & - & - & - & - & 1 \\
\hline Age & - & - & - & - & - & - & - & - & - & - & - \\
\hline Sex & - & - & - & - & - & - & - & - & - & - & - \\
\hline Alternatives Car & - & - & - & - & - & - & - & - & - & - & - \\
\hline $\begin{array}{l}\text { Alternatives } \\
\text { House }\end{array}$ & - & - & - & - & - & - & - & - & - & - & - \\
\hline Features Car & - & - & - & - & - & - & - & - & - & - & - \\
\hline Features House & - & - & - & - & - & - & - & - & - & - & - \\
\hline Affect scale car & - & - & - & - & - & - & - & - & - & - & - \\
\hline $\begin{array}{l}\text { Affect scale } \\
\text { house }\end{array}$ & - & - & - & - & - & - & - & - & - & - & - \\
\hline Car Decision & - & - & - & - & - & - & - & - & - & - & - \\
\hline House Decision & - & - & - & - & - & - & - & - & - & - & - \\
\hline
\end{tabular}

* significant at $p<.05$

$* *$ significant at $p<.01$ 
Table 5

Pearson Correlations - Part 3

\begin{tabular}{|c|c|c|c|c|c|c|c|c|c|c|}
\hline & Age & Sex & $\begin{array}{c}\text { Altern } \\
\text {-atives } \\
\text { Car }\end{array}$ & $\begin{array}{l}\text { Altern } \\
\text {-atives } \\
\text { House }\end{array}$ & $\begin{array}{c}\text { Featur } \\
\text {-es } \\
\text { Car } \\
\end{array}$ & $\begin{array}{c}\text { Featur } \\
\text {-es } \\
\text { House }\end{array}$ & $\begin{array}{c}\text { Affect } \\
\text { scale } \\
\text { car }\end{array}$ & $\begin{array}{l}\text { Affect } \\
\text { scale } \\
\text { house }\end{array}$ & $\begin{array}{c}\text { Car } \\
\text { Qualit- } \\
\text { y }\end{array}$ & $\begin{array}{c}\text { House } \\
\text { Qualit- } \\
\mathrm{y}\end{array}$ \\
\hline Choice Car A & -0.149 & 0.074 & 0.254 & 0.264 & $-.350^{*}$ & -0.053 & 0.083 & -0.060 & -0.128 & 0.140 \\
\hline \# Pieces Car A & -0.243 & 0.023 & 0.018 & $.413^{*}$ & -0.009 & -0.199 & -0.320 & -0.253 & 0.027 & -0.214 \\
\hline Time Car A & 0.009 & -0.102 & -0.030 & 0.102 & 0.004 & 0.053 & -0.261 & -0.102 & 0.062 & -0.144 \\
\hline Choice Car B & -0.015 & 0.037 & 0.223 & 0.123 & -0.281 & 0.124 & -0.033 & 0.038 & $.477^{* *}$ & 0.119 \\
\hline \# Pieces Car B & -0.298 & 0.253 & 0.152 & $.451^{*}$ & -0.067 & -0.245 & -0.062 & -0.078 & -0.009 & -0.017 \\
\hline Time Car B & -0.106 & 0.110 & -0.040 & 0.148 & 0.070 & -0.011 & -0.039 & 0.004 & 0.254 & 0.006 \\
\hline Choice House A & 0.195 & 0.091 & 0.120 & 0.014 & -0.148 & 0.023 & -0.049 & 0.210 & $.457^{*}$ & -0.036 \\
\hline \# Pieces House A & -0.281 & -0.131 & -0.217 & 0.108 & 0.232 & -0.152 & -0.003 & -0.288 & 0.061 & -0.074 \\
\hline Time House A & 0.082 & 0.005 & -0.172 & -0.149 & 0.154 & -0.033 & 0.089 & -0.263 & 0.313 & -0.024 \\
\hline Choice House B & -0.027 & -0.103 & -0.152 & 0.019 & 0.189 & 0.078 & 0.049 & 0.220 & 0.087 & -0.119 \\
\hline \# Pieces House B & -0.069 & 0.003 & -0.003 & 0.078 & -0.016 & -0.074 & 0.033 & -0.156 & $.442^{*}$ & -0.192 \\
\hline Time House B & 0.138 & -0.122 & -0.049 & -0.093 & -0.031 & 0.023 & 0.061 & -0.044 & $.424^{*}$ & -0.011 \\
\hline Four Choice & $.568^{* *}$ & -0.114 & 0.208 & -0.175 & -0.173 & 0.025 & 0.099 & 0.037 & 0.101 & -0.118 \\
\hline Letter Digit & $.577^{* *}$ & -0.059 & 0.220 & 0.037 & -0.256 & -0.143 & 0.223 & 0.000 & -0.280 & -0.104 \\
\hline Live Importance & -0.045 & 0.079 & -0.139 & $-.391^{* *}$ & 0.247 & $.397^{* *}$ & 0.140 & $.800^{* *}$ & -0.107 & 0.021 \\
\hline Live Meaningful & 0.089 & -0.218 & 0.110 & -0.182 & -0.066 & 0.206 & $.278^{*}$ & $.956^{* *}$ & -0.244 & 0.260 \\
\hline Live Difficulty & -0.083 & 0.026 & -0.037 & 0.042 & 0.079 & 0.037 & 0.219 & $.302^{*}$ & -0.304 & 0.096 \\
\hline Live Recency & $.608^{* *}$ & -0.024 & -0.021 & -0.083 & 0.153 & 0.054 & $.308^{*}$ & 0.116 & 0.319 & -0.295 \\
\hline Car Importance & 0.038 & -0.114 & -0.344 & -0.101 & 0.294 & -0.070 & $.888^{* *}$ & $.330^{*}$ & -0.118 & $-.317^{*}$ \\
\hline Car Meaningful & $.271^{*}$ & 0.035 & -0.055 & 0.174 & -0.023 & -0.205 & $.910^{* *}$ & 0.143 & -0.334 & $-.432^{* *}$ \\
\hline Car Difficulty & -0.148 & -0.225 & $-.594^{* *}$ & 0.140 & $.454^{*}$ & -0.109 & $.589^{* *}$ & 0.094 & -0.166 & -0.067 \\
\hline Car Recency & $.323^{*}$ & -0.266 & 0.074 & -0.144 & -0.090 & 0.023 & 0.025 & $.456^{* *}$ & -0.341 & 0.267 \\
\hline Age & 1 & -0.098 & 0.324 & -0.014 & -0.177 & 0.005 & 0.179 & 0.050 & 0.022 & $-.324^{*}$ \\
\hline Sex & - & 1 & -0.058 & -0.105 & 0.119 & 0.100 & -0.039 & -0.133 & 0.144 & -0.183 \\
\hline Alternatives Car & - & - & 1 & $.446^{*}$ & $-.884^{* *}$ & -0.297 & -0.228 & 0.044 & 0.022 & 0.010 \\
\hline $\begin{array}{l}\text { Alternatives } \\
\text { House }\end{array}$ & - & - & - & 1 & $-.539^{* *}$ & $-.817^{* * *}$ & 0.049 & $-.314^{*}$ & -0.234 & 0.038 \\
\hline Features Car & - & - & - & - & 1 & $.453^{*}$ & 0.158 & 0.021 & -0.077 & -0.085 \\
\hline Features House & - & - & - & - & - & 1 & -0.158 & $.333^{*}$ & 0.242 & -0.035 \\
\hline Affect scale car & - & - & - & - & - & - & 1 & 0.257 & -0.247 & $-.424^{* *}$ \\
\hline $\begin{array}{l}\text { Affect scale } \\
\text { house }\end{array}$ & - & - & - & - & - & - & - & 1 & -0.220 & 0.181 \\
\hline Car Decision & - & - & - & - & - & - & - & - & 1 & 0.027 \\
\hline House Decision & - & - & - & - & - & - & - & - & - & 1 \\
\hline
\end{tabular}

* significant at $p<.05$

$* *$ significant at $p<.01$ 
Table 6

Spearman's Rho Correlations - Part 1

\begin{tabular}{|c|c|c|c|c|c|c|c|c|c|c|c|}
\hline & \multirow{2}{*}{\multicolumn{3}{|c|}{$\#$}} & \multirow{2}{*}{\multicolumn{3}{|c|}{$\#$}} & \multicolumn{3}{|c|}{$\#$} & \multirow[b]{2}{*}{ Choice } & \multirow{3}{*}{$\begin{array}{c}\# \\
\text { Pieces } \\
\text { House }\end{array}$} \\
\hline & & & & & & & Choice & Pieces & Time & & \\
\hline & Choice & Pieces & Time & Choice & Pieces & Time & House & House & House & House & \\
\hline & Car A & Car A & Car A & Car B & Car B & Car B & $\mathrm{A}$ & $\mathrm{A}$ & $\mathrm{A}$ & $\mathrm{B}$ & B \\
\hline Choice Car A & 1 & 0.112 & -0.001 & 0.161 & 0.267 & 0.075 & -0.098 & -0.258 & -0.366 & 0.118 & 0.058 \\
\hline \# Pieces Car A & - & 1 & $.744^{* *}$ & -0.070 & $.604^{* *}$ & $.581^{* *}$ & 0.194 & $.489^{*}$ & $.538^{* *}$ & $.582^{* *}$ & $.697^{* *}$ \\
\hline Time Car A & - & - & 1 & -0.155 & 0.264 & $.518^{* *}$ & $.542^{* * *}$ & 0.190 & $.483^{*}$ & 0.396 & $.488^{*}$ \\
\hline Choice Car B & - & - & - & 1 & -0.025 & -0.055 & 0.181 & -0.365 & -0.318 & -0.222 & -0.134 \\
\hline \# Pieces Car B & - & - & - & - & 1 & $.781^{* *}$ & 0.126 & $.498^{*}$ & 0.394 & $.674^{* *}$ & $.572^{* * *}$ \\
\hline Time Car B & - & - & - & - & - & 1 & $.405^{*}$ & 0.369 & $.544^{* *}$ & $.616^{* *}$ & $.702^{* *}$ \\
\hline Choice House A & - & - & - & - & - & - & 1 & -0.208 & -0.117 & 0.292 & 0.028 \\
\hline \# Pieces House A & - & - & - & - & - & - & - & 1 & $.618^{* *}$ & $.302^{*}$ & $.427^{* *}$ \\
\hline Time House A & - & - & - & - & - & - & - & - & 1 & 0.224 & $.416^{* *}$ \\
\hline Choice House B & - & - & - & - & - & - & - & - & - & 1 & $.413^{* *}$ \\
\hline \# Pieces House B & - & - & - & - & - & - & - & - & - & - & 1 \\
\hline Time House B & - & - & - & - & - & - & - & - & - & - & - \\
\hline Four Choice & - & - & - & - & - & - & - & - & - & - & - \\
\hline Letter Digit & - & - & - & - & - & - & - & - & - & - & - \\
\hline Live Importance & - & - & - & - & - & - & - & - & - & - & - \\
\hline Live Meaningful & - & - & - & - & - & - & - & - & - & - & - \\
\hline Live Difficulty & - & - & - & - & - & - & - & - & - & - & - \\
\hline Live Recency & - & - & - & - & - & - & - & - & - & - & - \\
\hline Car Importance & - & - & - & - & - & - & - & - & - & - & - \\
\hline Car Meaningful & - & - & - & - & - & - & - & - & - & - & - \\
\hline Car Difficulty & - & - & - & - & - & - & - & - & - & - & - \\
\hline Car Recency & - & - & - & - & - & - & - & - & - & - & - \\
\hline Age & - & - & - & - & - & - & - & - & - & - & - \\
\hline Sex & - & - & - & - & - & - & - & - & - & - & - \\
\hline Alternatives Car & - & - & - & - & - & - & - & - & - & - & - \\
\hline $\begin{array}{l}\text { Alternatives } \\
\text { House }\end{array}$ & - & - & - & - & - & - & - & - & - & - & - \\
\hline Features Car & - & - & - & - & - & - & - & - & - & - & - \\
\hline Features House & - & - & - & - & - & - & - & - & - & - & - \\
\hline Affect scale car & - & - & - & - & - & - & - & - & - & - & - \\
\hline $\begin{array}{l}\text { Affect scale } \\
\text { house }\end{array}$ & - & - & - & - & - & - & - & - & - & - & - \\
\hline Car Decision & - & - & - & - & - & - & - & - & - & - & - \\
\hline House Decision & - & - & - & - & - & - & - & - & - & - & - \\
\hline
\end{tabular}

$*$ significant at $p<.05$

$* *$ significant at $p<.01$ 
Table 7

Spearman's Rho Correlations - Part 2

\begin{tabular}{|c|c|c|c|c|c|c|c|c|c|c|c|}
\hline & $\begin{array}{c}\text { Time } \\
\text { House } \\
\text { B } \\
\end{array}$ & $\begin{array}{c}\text { Four } \\
\text { Choice }\end{array}$ & $\begin{array}{l}\text { Letter } \\
\text { Digit }\end{array}$ & $\begin{array}{c}\text { Live } \\
\text { Import } \\
\text {-ance }\end{array}$ & $\begin{array}{c}\text { Live } \\
\text { Meani } \\
\text {-ngful }\end{array}$ & $\begin{array}{c}\text { Live } \\
\text { Diffic- } \\
\text { ulty }\end{array}$ & $\begin{array}{c}\text { Live } \\
\text { Recen- } \\
\text { cy }\end{array}$ & $\begin{array}{c}\text { Car } \\
\text { Import } \\
\text {-ance }\end{array}$ & $\begin{array}{c}\text { Car } \\
\text { Meani } \\
\text {-ngful }\end{array}$ & $\begin{array}{c}\text { Car } \\
\text { Diffic- } \\
\text { ulty }\end{array}$ & $\begin{array}{c}\text { Car } \\
\text { Recen- } \\
\text { cy }\end{array}$ \\
\hline Choice Car A & 0.132 & -0.173 & -0.095 & -0.240 & 0.049 & -0.118 & -0.133 & -0.007 & 0.227 & 0.054 & -0.156 \\
\hline \# Pieces Car A & $.516^{* *}$ & -0.086 & -0.235 & -0.153 & -0.294 & -0.152 & -0.282 & $-.498^{* *}$ & -0.266 & -0.085 & -0.286 \\
\hline Time Car A & $.558^{* *}$ & 0.220 & 0.044 & -0.070 & -0.101 & -0.137 & -0.018 & -0.326 & -0.126 & -0.008 & -0.250 \\
\hline Choice Car B & 0.015 & 0.118 & 0.009 & -0.137 & -0.031 & 0.017 & 0.250 & 0.004 & -0.102 & -0.193 & -0.180 \\
\hline \# Pieces Car B & $.408^{*}$ & -0.274 & -0.347 & -0.052 & 0.060 & 0.170 & -0.151 & -0.140 & 0.061 & 0.089 & -0.220 \\
\hline Time Car B & $.690^{* *}$ & 0.101 & -0.127 & -0.023 & 0.061 & -0.010 & 0.078 & -0.060 & 0.088 & 0.307 & -0.235 \\
\hline Choice House A & 0.075 & 0.158 & 0.160 & 0.207 & 0.228 & -0.193 & 0.252 & 0.049 & -0.103 & 0.036 & -0.015 \\
\hline \# Pieces House A & 0.124 & -0.290 & $-.409^{* *}$ & 0.073 & -0.194 & 0.118 & -0.263 & -0.175 & -0.202 & -0.008 & -0.240 \\
\hline Time House A & $.483^{* *}$ & 0.180 & 0.032 & -0.085 & -0.252 & 0.032 & 0.122 & -0.022 & 0.114 & 0.011 & -0.087 \\
\hline Choice House B & 0.282 & -0.020 & -0.101 & 0.123 & 0.173 & -0.041 & 0.078 & 0.152 & 0.135 & 0.176 & -0.112 \\
\hline \# Pieces House B & $.697^{* *}$ & -0.199 & -0.207 & 0.079 & -0.144 & 0.018 & -0.004 & -0.021 & 0.078 & 0.194 & $-.471^{* *}$ \\
\hline Time House B & 1 & 0.196 & 0.093 & -0.178 & -0.100 & -0.056 & $.317^{*}$ & -0.046 & 0.147 & 0.139 & -0.235 \\
\hline Four Choice & - & 1 & $.707^{* *}$ & -0.048 & 0.042 & -0.108 & $.460^{* *}$ & 0.214 & 0.173 & -0.057 & $.308^{*}$ \\
\hline Letter Digit & - & - & 1 & -0.046 & -0.051 & 0.006 & $.309^{*}$ & 0.138 & $.362^{*}$ & 0.007 & $.295^{*}$ \\
\hline Live Importance & - & - & - & 1 & $.567^{* *}$ & $.291^{*}$ & 0.024 & 0.248 & 0.018 & 0.073 & 0.268 \\
\hline Live Meaningful & - & - & - & - & 1 & $.329^{*}$ & 0.103 & 0.264 & 0.081 & 0.071 & $.491^{* * *}$ \\
\hline Live Difficulty & - & - & - & - & - & 1 & -0.026 & $.280^{*}$ & 0.160 & $.448^{* *}$ & 0.159 \\
\hline Live Recency & - & - & - & - & - & - & 1 & $.290^{*}$ & 0.252 & 0.098 & 0.037 \\
\hline Car Importance & - & - & - & - & - & - & - & 1 & $.602^{* *}$ & $.556^{* *}$ & 0.015 \\
\hline Car Meaningful & - & - & - & - & - & - & - & - & 1 & $.449^{* *}$ & 0.007 \\
\hline Car Difficulty & - & - & - & - & - & - & - & - & - & 1 & -0.011 \\
\hline Car Recency & - & - & - & - & - & - & - & - & - & - & 1 \\
\hline Age & - & - & - & - & - & - & - & - & - & - & - \\
\hline Sex & - & - & - & - & - & - & - & - & - & - & - \\
\hline Alternatives Car & - & - & - & - & - & - & - & - & - & - & - \\
\hline $\begin{array}{l}\text { Alternatives } \\
\text { House }\end{array}$ & - & - & - & - & - & - & - & - & - & - & - \\
\hline Features Car & - & - & - & - & - & - & - & - & - & - & - \\
\hline Features House & - & - & - & - & - & - & - & - & - & - & - \\
\hline Affect scale car & - & - & - & - & - & - & - & - & - & - & - \\
\hline $\begin{array}{l}\text { Affect scale } \\
\text { house }\end{array}$ & - & - & - & - & - & - & - & - & - & - & - \\
\hline Car Decision & - & - & - & - & - & - & - & - & - & - & - \\
\hline House Decision & - & - & - & - & - & - & - & - & - & - & - \\
\hline
\end{tabular}

* significant at $p<.05$

$* *$ significant at $p<.01$ 
Table 8

Spearman's Rho Correlations - Part 3

\begin{tabular}{|c|c|c|c|c|c|c|c|c|c|c|}
\hline & Age & Sex & $\begin{array}{c}\text { Altern } \\
\text {-atives } \\
\text { Car }\end{array}$ & $\begin{array}{c}\text { Altern } \\
\text {-atives } \\
\text { House } \\
\end{array}$ & $\begin{array}{c}\text { Featur } \\
\text {-es } \\
\text { Car }\end{array}$ & $\begin{array}{c}\text { Featur } \\
\text {-es } \\
\text { House }\end{array}$ & $\begin{array}{c}\text { Affect } \\
\text { scale } \\
\text { car }\end{array}$ & $\begin{array}{c}\text { Affect } \\
\text { scale } \\
\text { house }\end{array}$ & $\begin{array}{c}\text { Car } \\
\text { Qualit- } \\
\text { y }\end{array}$ & $\begin{array}{c}\text { House } \\
\text { Qualit- } \\
\mathrm{y}\end{array}$ \\
\hline Choice Car A & -0.174 & 0.028 & 0.212 & 0.192 & -0.278 & -0.008 & 0.107 & 0.014 & -0.213 & 0.086 \\
\hline \# Pieces Car A & -0.102 & 0.103 & 0.091 & 0.343 & -0.091 & -0.189 & $-.449^{*}$ & -0.280 & 0.155 & -0.077 \\
\hline Time Car A & 0.129 & -0.039 & 0.035 & 0.115 & -0.014 & 0.094 & -0.268 & -0.092 & 0.129 & -0.167 \\
\hline Choice Car B & -0.085 & 0.088 & $.366^{*}$ & 0.105 & $-.375^{*}$ & 0.149 & -0.074 & -0.054 & $.472^{* *}$ & 0.122 \\
\hline \# Pieces Car B & -0.242 & $.356^{*}$ & 0.164 & 0.325 & -0.167 & -0.156 & -0.067 & 0.059 & 0.088 & 0.101 \\
\hline Time Car B & -0.076 & 0.133 & -0.070 & 0.143 & 0.023 & -0.016 & -0.008 & 0.059 & 0.257 & -0.024 \\
\hline Choice House A & 0.133 & 0.109 & 0.116 & 0.014 & -0.116 & 0.047 & -0.038 & 0.214 & $.473^{*}$ & -0.016 \\
\hline \# Pieces House A & -0.221 & -0.129 & -0.227 & -0.007 & 0.201 & 0.058 & -0.221 & -0.104 & 0.090 & 0.130 \\
\hline Time House A & 0.162 & 0.069 & -0.186 & -0.141 & 0.132 & 0.011 & 0.062 & -0.189 & 0.277 & -0.024 \\
\hline Choice House B & 0.079 & -0.081 & -0.212 & 0.066 & 0.208 & 0.058 & 0.149 & 0.161 & 0.109 & -0.259 \\
\hline \# Pieces House B & -0.113 & 0.094 & -0.041 & 0.111 & -0.023 & 0.043 & 0.015 & -0.073 & $.418^{*}$ & -0.180 \\
\hline Time House B & 0.220 & -0.081 & 0.071 & 0.015 & -0.105 & 0.024 & 0.051 & -0.134 & $.511^{* *}$ & -0.060 \\
\hline Four Choice & $.611^{* *}$ & -0.205 & 0.189 & -0.154 & -0.158 & 0.046 & 0.199 & 0.021 & 0.004 & -0.140 \\
\hline Letter Digit & $.560^{* *}$ & -0.068 & 0.200 & 0.019 & -0.275 & -0.132 & $.288^{*}$ & -0.062 & -0.324 & -0.166 \\
\hline Live Importance & -0.057 & 0.079 & -0.122 & -0.263 & 0.157 & $.319^{*}$ & 0.144 & $.735^{* *}$ & -0.107 & 0.021 \\
\hline Live Meaningful & -0.049 & -0.129 & 0.050 & -0.226 & -0.027 & 0.240 & 0.185 & $.951^{* *}$ & -0.235 & 0.260 \\
\hline Live Difficulty & -0.093 & 0.051 & -0.086 & 0.031 & 0.057 & 0.057 & 0.241 & $.330^{*}$ & -0.311 & 0.112 \\
\hline Live Recency & $.571^{* *}$ & -0.006 & 0.052 & -0.093 & 0.099 & 0.081 & $.287^{*}$ & 0.053 & 0.325 & -0.299 \\
\hline Car Importance & 0.007 & -0.060 & $-.386^{*}$ & -0.165 & 0.336 & -0.017 & $.867^{* *}$ & $.285^{*}$ & -0.122 & $-.324^{*}$ \\
\hline Car Meaningful & $.274^{*}$ & 0.043 & -0.059 & 0.195 & -0.011 & -0.216 & $.915^{* *}$ & 0.068 & -0.318 & $-.447^{* *}$ \\
\hline Car Difficulty & -0.124 & -0.222 & $-.619^{* *}$ & 0.132 & $.490^{* *}$ & -0.094 & $.549^{* *}$ & 0.043 & -0.184 & -0.053 \\
\hline Car Recency & $.305^{*}$ & -0.251 & 0.023 & -0.202 & -0.052 & 0.045 & 0.031 & $.458^{* *}$ & -0.334 & 0.273 \\
\hline Age & 1 & -0.115 & 0.263 & -0.008 & -0.110 & 0.047 & 0.156 & -0.062 & 0.017 & $-.357^{*}$ \\
\hline Sex & - & 1 & -0.098 & -0.043 & 0.070 & 0.090 & 0.009 & -0.077 & 0.144 & -0.183 \\
\hline Alternatives Car & - & - & 1 & $.501^{*}$ & $-.900^{* *}$ & -0.250 & -0.283 & 0.023 & 0.112 & -0.036 \\
\hline $\begin{array}{l}\text { Alternatives } \\
\text { House }\end{array}$ & - & - & - & 1 & $-.598^{* *}$ & $-.767^{* *}$ & 0.030 & $-.304^{*}$ & -0.167 & -0.012 \\
\hline Features Car & - & - & - & - & 1 & $.427^{*}$ & 0.212 & 0.003 & -0.122 & -0.083 \\
\hline Features House & - & - & - & - & - & 1 & -0.151 & $.326^{*}$ & 0.256 & -0.016 \\
\hline Affect scale car & - & - & - & - & - & - & 1 & 0.188 & -0.240 & $-.430^{* *}$ \\
\hline $\begin{array}{l}\text { Affect scale } \\
\text { house }\end{array}$ & - & - & - & - & - & - & - & 1 & -0.225 & 0.203 \\
\hline Car Decision & - & - & - & - & - & - & - & - & 1 & 0.027 \\
\hline House Decision & - & - & - & - & - & - & - & - & - & 1 \\
\hline
\end{tabular}

$*$ significant at $p<.05$

$* *$ significant at $p<.01$ 


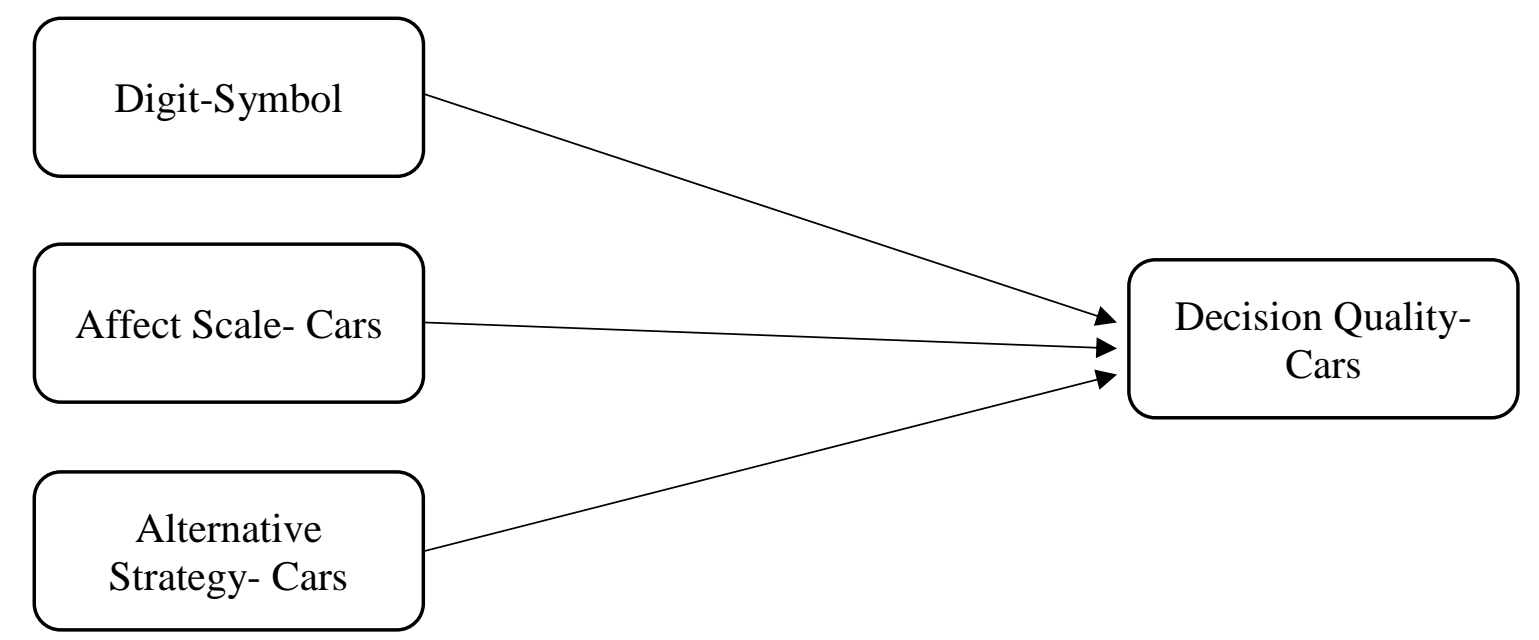

Figure 1.

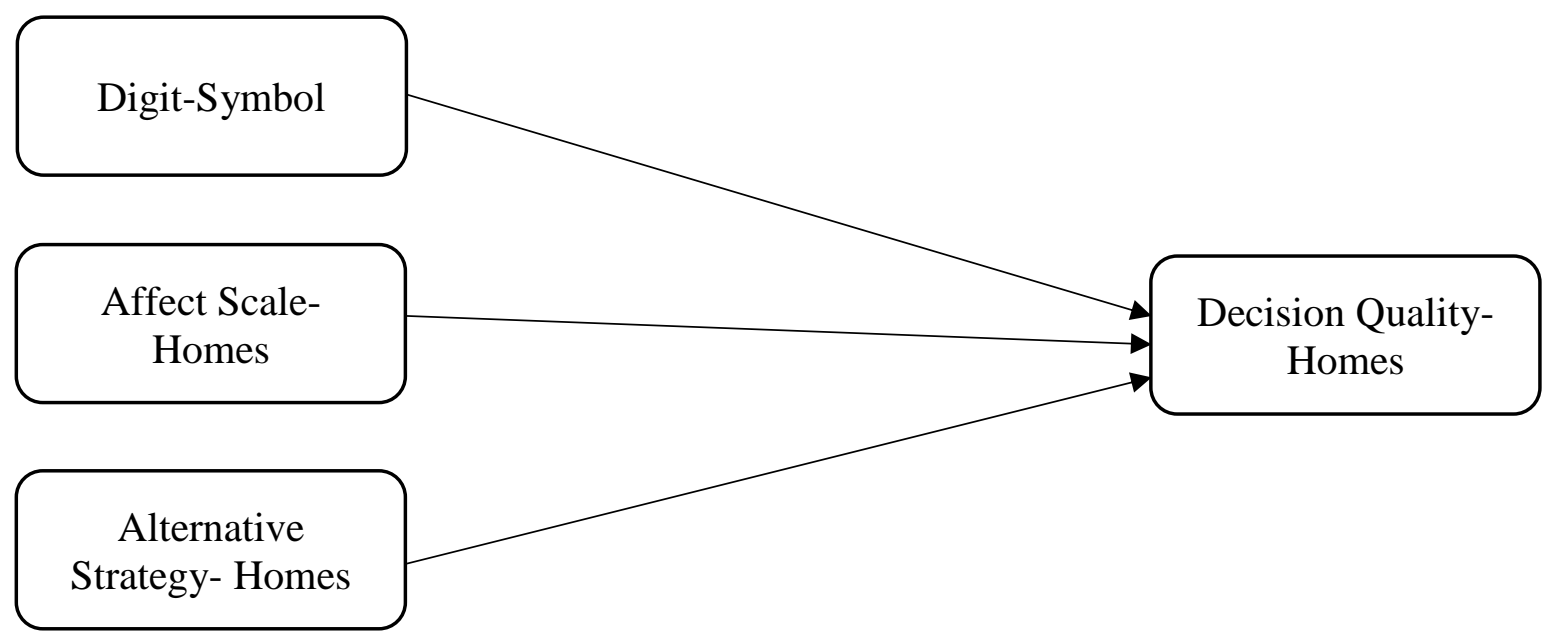

Figure 2.

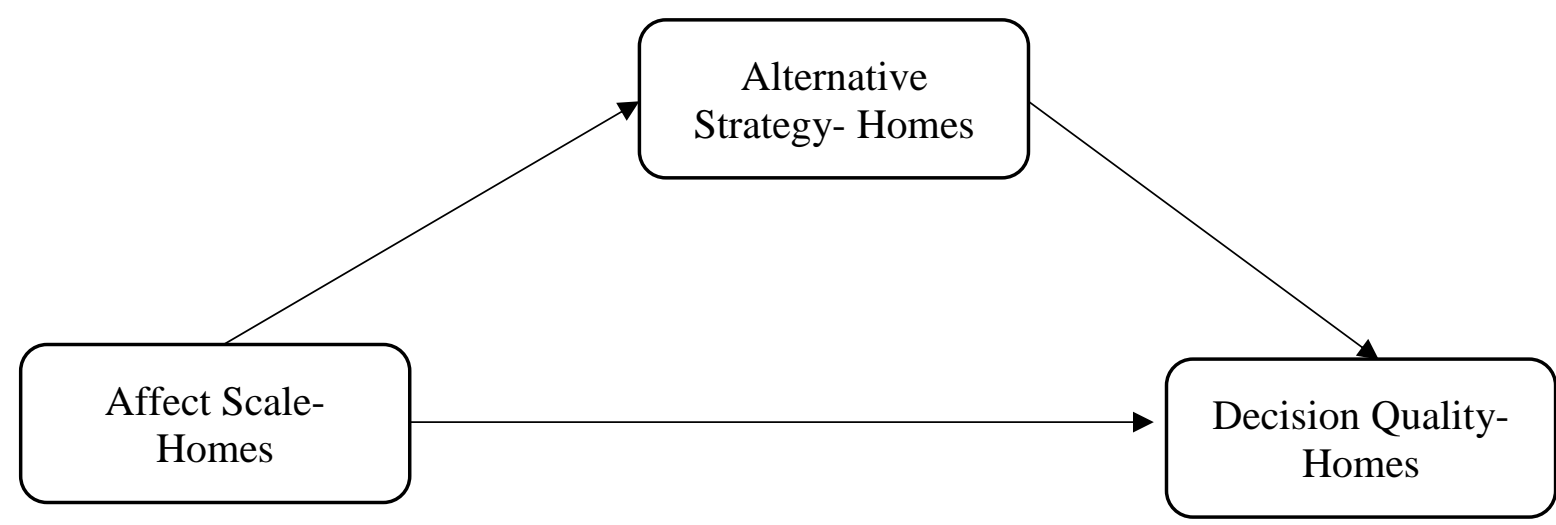

Figure 3. 


\section{Appendix A}

\begin{tabular}{|c|c|c|c|c|c|c|c|c|}
\hline \multicolumn{9}{|c|}{ SELF } \\
\hline & Rent & Size & Locale & Medical Services & $\begin{array}{l}\text { Non-Medical } \\
\text { Services }\end{array}$ & Social & Safety & Rules/Options \\
\hline 1. & $\begin{array}{l}\text { \$2,775; utilities; } \\
\text { No Medicaid or } \\
\text { Medicare }\end{array}$ & $\begin{array}{l}\text { Average; } 1 \\
\text { bedroom; } 1 \\
\text { bath; } 550 \text { sqft. }\end{array}$ & $\begin{array}{l}\text { Good; Near large } \\
\text { metropolitan area }\end{array}$ & $\begin{array}{l}\text { Limited; Registered } \\
\text { nurse during day; } \\
\text { Personal Care } \\
\text { Assistants 24-hr. }\end{array}$ & $\begin{array}{l}\text { Excellent; laundry, } \\
\text { heavy housework; } \\
1 \text { full \& } 2 \text { light } \\
\text { meals }\end{array}$ & $\begin{array}{l}\text { Excellent; All } \\
\text { seniors; On-site } \\
\text { exercise room; } \\
\text { daily programs }\end{array}$ & $\begin{array}{l}\text { Excellent; } \\
\text { Reception desk \& } \\
\text { alarm at entry; } \\
\text { each unit has } \\
\text { private system }\end{array}$ & $\begin{array}{l}\text { Visitors can stay } \\
\text { over; middle } \\
\text { sized cat/dog } \\
\text { with deposit }\end{array}$ \\
\hline 2. & $\begin{array}{l}\text { \$930; utilities; No } \\
\text { Medicaid or } \\
\text { Medicare }\end{array}$ & $\begin{array}{l}\text { Small; } 1 \\
\text { bedroom, } 1 \\
\text { bath; } 448 \text { sqft. }\end{array}$ & $\begin{array}{l}\text { Excellent; Near } \\
\text { large city; close to } \\
\text { shopping and } \\
\text { recreation }\end{array}$ & $\begin{array}{l}\text { Limited; } 24-\mathrm{hr} \text {. } \\
\text { emergency call } \\
\text { system; weekly visit } \\
\text { by RN }\end{array}$ & $\begin{array}{l}\text { Very good; } \\
\text { laundry facilities, } \\
\text { full dinner, } 2 \text { light } \\
\text { meals }\end{array}$ & $\begin{array}{l}\text { Very good; All } \\
\text { seniors; daily } \\
\text { classes \& } \\
\text { programs }\end{array}$ & $\begin{array}{l}\text { Very good; } \\
\text { security entrance; } \\
\text { each unit has } \\
\text { double locks }\end{array}$ & $\begin{array}{l}\text { No pets; daily } \\
\text { visitors, cannot } \\
\text { stay over }\end{array}$ \\
\hline 3. & $\begin{array}{l}\$ 600 ; \text { No utilities; } \\
\text { No Medicaid or } \\
\text { Medicare }\end{array}$ & $\begin{array}{l}\text { Large; } 2 \\
\text { bedrooms; } 1 \\
\text { and one-half } \\
\text { bath; } 1220 \text { sqft. }\end{array}$ & $\begin{array}{l}\text { Average; Near } \\
\text { downtown area; } \\
\text { near business } \\
\text { district, hospitals }\end{array}$ & $\begin{array}{l}\text { Poor; No services } \\
\text { offered }\end{array}$ & $\begin{array}{l}\text { Good; Indoor } \\
\text { pool; exercise \& } \\
\text { recreation rooms; } \\
\text { coin laundry }\end{array}$ & $\begin{array}{l}\text { Poor; No } \\
\text { planned } \\
\text { activities; mix of } \\
\text { age groups \& } \\
\text { nationalities } \\
\end{array}$ & $\begin{array}{l}\text { Average; Private, } \\
\text { external key - lock } \\
\text { entry to units }\end{array}$ & $\begin{array}{l}\text { No pets; visitors } \\
\text { can stay over }\end{array}$ \\
\hline 4. & $\begin{array}{l}\text { \$4,152; utilities; } \\
\text { Medicare \& } \\
\text { Medicaid accepted }\end{array}$ & $\begin{array}{l}\text { Small; } 1 \\
\text { bedroom; } 1 \\
\text { bath; } 300 \text { sqft. }\end{array}$ & $\begin{array}{l}\text { Excellent; near } \\
\text { large metro area; } \\
\text { landscaped ground }\end{array}$ & $\begin{array}{l}\text { Excellent; complete, } \\
24-\text { hr. physician \& } \\
\text { RN's; acute care }\end{array}$ & $\begin{array}{l}\text { Excellent; } 3 \text { full } \\
\text { meals; } \\
\text { housekeeping, } \\
\text { laundry, personal } \\
\text { care }\end{array}$ & $\begin{array}{l}\text { Very good; All } \\
\text { seniors; } \\
\text { activities } \\
\text { director; daily } \\
\text { programs }\end{array}$ & $\begin{array}{l}\text { Good; electronic } \\
\text { key entry to } \\
\text { building }\end{array}$ & $\begin{array}{l}\text { No pets; daily } \\
\text { visitors; cannot } \\
\text { stay }\end{array}$ \\
\hline 5. & $\begin{array}{l}\$ 2,000 ; \text { utilities; } \\
\text { Medicare \& } \\
\text { Medicaid accepted }\end{array}$ & $\begin{array}{l}\text { Average; } 4 \\
\text { bedroom; } 2 \\
\text { baths; } 950 \text { sqft. }\end{array}$ & $\begin{array}{l}\text { Good; suburban, } \\
\text { residential area; } \\
\text { near shopping }\end{array}$ & $\begin{array}{l}\text { Good; Daily visiting } \\
\text { nurse; trained house } \\
\text { - supervisor }\end{array}$ & $\begin{array}{l}\text { Very good; } 3 \text { full } \\
\text { meals; laundry, } \\
\text { housekeeping }\end{array}$ & $\begin{array}{l}\text { Good; all } \\
\text { seniors; daily } \\
\text { activities \& } \\
\text { weekly trips }\end{array}$ & $\begin{array}{l}\text { Good; key pad } \\
\text { entry; security } \\
\text { station }\end{array}$ & $\begin{array}{l}\text { Pets with deposit; } \\
\text { visitors cannot } \\
\text { stay }\end{array}$ \\
\hline 6. & $\begin{array}{l}\text { \$1,200; utilities; } \\
\text { Medicare \& } \\
\text { Medicaid accepted }\end{array}$ & $\begin{array}{l}\text { Small; } 1 \\
\text { bedroom; } 1 \\
\text { bath; } 300 \text { sqft. }\end{array}$ & $\begin{array}{l}\text { Average; near } \\
\text { urban area }\end{array}$ & $\begin{array}{l}\text { Good; complete, } 24 \\
\text { - hr. physician; } \\
\text { acute care }\end{array}$ & $\begin{array}{l}\text { Good; } 3 \text { full meals; } \\
\text { housekeeping, } \\
\text { laundry, personal } \\
\text { care }\end{array}$ & $\begin{array}{l}\text { Good; All } \\
\text { seniors; daily } \\
\text { programs, crafts }\end{array}$ & $\begin{array}{l}\text { Average; } \\
\text { receptionist at } \\
\text { building entry }\end{array}$ & $\begin{array}{l}1 \text { pet under } 10 \\
\text { lbs. with deposit; } \\
\text { visitors can stay }\end{array}$ \\
\hline 7. & $\begin{array}{l}\$ 1,295 ; \text { utilities; } \\
\text { No Medicaid or } \\
\text { Medicare }\end{array}$ & $\begin{array}{l}\text { Large; } 2 \\
\text { bedrooms; } 2 \\
\text { baths; } 2200 \\
\text { sqft. }\end{array}$ & $\begin{array}{l}\text { Excellent; near } \\
\text { suburban } \\
\text { shopping; } \\
\text { landscaped } \\
\text { grounds }\end{array}$ & Poor; emergency call & $\begin{array}{l}\text { Average; coin } \\
\text { laundry; light } \\
\text { breakfast }\end{array}$ & $\begin{array}{l}\text { Average; Age- } \\
\text { mixed residents; } \\
\text { indoor pool }\end{array}$ & $\begin{array}{l}\text { Very good; } \\
\text { electronic entry to } \\
\text { building and units }\end{array}$ & $\begin{array}{l}\text { Pets under } 50 \text { lbs. } \\
\text { with deposit; } \\
\text { visitors anytime }\end{array}$ \\
\hline 8. & $\begin{array}{l}\text { \$400; utilities; No } \\
\text { Medicaid or } \\
\text { Medicare }\end{array}$ & $\begin{array}{l}\text { Average; } 1 \\
\text { bedroom; } 1 \\
\text { bath; } 550 \text { sqft. }\end{array}$ & $\begin{array}{l}\text { Good; suburban } \\
\text { area; on bus line } \\
\text { to shopping }\end{array}$ & $\begin{array}{l}\text { Poor; no services } \\
\text { offered }\end{array}$ & $\begin{array}{l}\text { Poor; no laundry } \\
\text { or recreation } \\
\text { areas }\end{array}$ & $\begin{array}{l}\text { Limited; age - } \\
\text { mixed residents }\end{array}$ & $\begin{array}{l}\text { Average; private } \\
\text { entry, standard } \\
\text { locks }\end{array}$ & $\begin{array}{l}\text { Pets allowed; no } \\
\text { deposit required; } \\
\text { visitors cannot } \\
\text { stay }\end{array}$ \\
\hline
\end{tabular}


Anna is a 65-year-old widow who currently lives along in her third floor apartment in the city. Her 40-year-old daughter visits her twice daily to cook and clean for Anna since her physical health is so poor. Due to diabetes, she is unable to walk and her vision is poor. Anna lives on less than $\$ 600$ a month from Social Security and her husband's pension. Her only visitors are her daughter and son-in-law, even though Anna had once been quite active in community groups. She complains the she misses being with others and that she doesn't want to continue to burden her daughter. Anna is thinking about moving to a new home.

\begin{tabular}{|c|c|c|c|c|c|c|c|c|}
\hline & Rent & Size & Locale & Medical Services & Non-Medical Services & Social & Safety & Rules/Options \\
\hline 1. & $\begin{array}{l}\text { \$1,505 per month; } \\
\text { utilities; No } \\
\text { Medicaid or } \\
\text { Medicare }\end{array}$ & $\begin{array}{l}\text { Average; } 2 \text { bedrooms; } \\
1 \text { bath; } 950 \text { sqft. }\end{array}$ & $\begin{array}{l}\text { Good; Near large } \\
\text { city }\end{array}$ & $\begin{array}{l}\text { Good; Full - time RN } \\
\text { \& personal care } \\
\text { assistants }\end{array}$ & $\begin{array}{l}\text { Excellent; } \\
\text { housekeeping services; } \\
2 \text { meals; pharmacy }\end{array}$ & $\begin{array}{l}\text { Excellent; All } \\
\text { seniors; exercise } \\
\text { room; daily } \\
\text { activities }\end{array}$ & $\begin{array}{l}\text { Excellent; Reception } \\
\text { desk \& alarm; } \\
\text { private alarms }\end{array}$ & $\begin{array}{l}\text { Pets with deposit; } \\
\text { visitors cannot } \\
\text { stay }\end{array}$ \\
\hline 2. & $\begin{array}{l}\text { \$300 per month; No } \\
\text { utilities paid; } \\
\text { Medicaid \& } \\
\text { Medicare }\end{array}$ & $\begin{array}{l}\text { Average; } 1 \text { bedroom; } \\
1 \text { bath; } 900 \text { sqft. }\end{array}$ & $\begin{array}{l}\text { Poor; Downtown } \\
\text { area; close to } \\
\text { business district \& } \\
\text { night clubs }\end{array}$ & $\begin{array}{l}\text { Good; trained } \\
\text { supervisor; } 24 \mathrm{hr} \text {. } \\
\text { emergency call }\end{array}$ & $\begin{array}{l}\text { Average; party room; } \\
\text { billiards; laundry }\end{array}$ & $\begin{array}{l}\text { No planned } \\
\text { activities; adults } \\
\text { only, many with } \\
\text { disabilities }\end{array}$ & $\begin{array}{l}\text { Average; Reception } \\
\text { desk at entry; } \\
\text { individual key-lock } \\
\text { entry }\end{array}$ & $\begin{array}{l}\text { No pets; visitors } \\
\text { anytime }\end{array}$ \\
\hline 3. & $\begin{array}{l}\$ 1,100 \text { per month; } \\
\text { utilities, Medicare \& } \\
\text { Medicaid accepted }\end{array}$ & $\begin{array}{l}\text { Small; } 1 \text { bedroom; } 1 \\
\text { bath; } 300 \text { sqft. }\end{array}$ & $\begin{array}{l}\text { Average; secluded } \\
\text { grounds; } 40 \text { miles } \\
\text { from nearest city }\end{array}$ & $\begin{array}{l}\text { Excellent; } 24-\mathrm{hr} . \\
\text { physician } \& \text { nurses; } \\
\text { acute care facilities }\end{array}$ & $\begin{array}{l}\text { Excellent; } 3 \text { meals; } \\
\text { housekeeping \& } \\
\text { personal care }\end{array}$ & $\begin{array}{l}\text { Very good; Frail } \\
\text { seniors; Full - } \\
\text { time therapist; } \\
\text { daily programs }\end{array}$ & $\begin{array}{l}\text { Good; electronic } \\
\text { entry to building; } \\
\text { low security for } \\
\text { individual units }\end{array}$ & $\begin{array}{l}\text { No pets; visiting } \\
\text { hours }\end{array}$ \\
\hline 4. & $\begin{array}{l}\text { \$975 per month; } \\
\text { utilities; No } \\
\text { Medicaid or } \\
\text { Medicare }\end{array}$ & $\begin{array}{l}\text { Large; } 1 \text { bedroom, } 1 \\
\text { bath; } 808 \text { sqft. }\end{array}$ & $\begin{array}{l}\text { Excellent; Near } \\
\text { large suburban } \\
\text { area; close to } \\
\text { shopping; bus line }\end{array}$ & $\begin{array}{l}\text { Limited; } 24-\mathrm{hr} . \\
\text { emergency call } \\
\text { system; weekly health } \\
\text { screenings }\end{array}$ & $\begin{array}{l}\text { Very good; in-house } \\
\text { coin laundry; three } \\
\text { light meals }\end{array}$ & $\begin{array}{l}\text { Very good; All } \\
\text { seniors; daily } \\
\text { classes \& } \\
\text { programs; weekly } \\
\text { trips }\end{array}$ & $\begin{array}{l}\text { Very good; } \\
\text { electronic - key } \\
\text { entrance; each unit } \\
\text { has double locks }\end{array}$ & $\begin{array}{l}\text { Pets under } 10 \text { lbs. } \\
\text { with deposit, } \\
\text { visitors can stay }\end{array}$ \\
\hline 5. & $\begin{array}{l}\$ 800 \text { per month; } \\
\text { some utilities; No } \\
\text { Medicare or } \\
\text { Medicaid }\end{array}$ & $\begin{array}{l}\text { Average; } 2 \text { bedrooms; } \\
1 \text { bath; } 950 \text { sqft. }\end{array}$ & $\begin{array}{l}\text { Good; suburban - } \\
\text { metro area; near } \\
\text { shopping \& } \\
\text { recreation }\end{array}$ & $\begin{array}{l}\text { Good; weekly health } \\
\text { screens; } 24 \mathrm{hr} \text {. } \\
\text { emergency call }\end{array}$ & $\begin{array}{l}\text { Very good; } 2 \text { light } \\
\text { meals daily; laundry \& } \\
\text { housekeeping }\end{array}$ & $\begin{array}{l}\text { Good; all seniors; } \\
\text { daily activities \& } \\
\text { weekly trips }\end{array}$ & $\begin{array}{l}\text { Average; electronic } \\
\text { entry to building } \\
\text { and units }\end{array}$ & $\begin{array}{l}2 \text { pets with } \\
\text { deposit, pet } \\
\text { walking area; } \\
\text { visiting hours }\end{array}$ \\
\hline 6. & $\begin{array}{l}\text { \$895 per month; } \\
\text { utilities; No } \\
\text { Medicaid or } \\
\text { Medicare }\end{array}$ & $\begin{array}{l}\text { Large; } 2 \text { bedrooms; } 1 \\
\text { bath; } 1200 \text { sqft. }\end{array}$ & $\begin{array}{l}\text { Excellent; near } \\
\text { suburban shopping, } \\
\text { recreation, \& } \\
\text { cultural events }\end{array}$ & $\begin{array}{l}\text { Poor; no extra } \\
\text { services }\end{array}$ & Average; coin laundry & $\begin{array}{l}\text { Average; age - } \\
\text { mixed residents; } \\
\text { party room, } \\
\text { exercise room; } \\
\text { tennis courts }\end{array}$ & $\begin{array}{l}\text { Good; standard } \\
\text { external key entry } \\
\text { to building and units }\end{array}$ & $\begin{array}{l}\text { Pet under } 50 \text { lbs. } \\
\text { with deposit, } \\
\text { visitors can stay } \\
\text { over }\end{array}$ \\
\hline 7. & $\begin{array}{l}\text { \$500 per month; No } \\
\text { utilities; No } \\
\text { Medicaid or } \\
\text { Medicare }\end{array}$ & $\begin{array}{l}\text { Average; } 1 \text { bedroom; } \\
1 \text { bath; } 550 \text { sqft. }\end{array}$ & $\begin{array}{l}\text { Poor; urban, } \\
\text { business area; on } \\
\text { bus line to } \\
\text { shopping }\end{array}$ & $\begin{array}{l}\text { Poor; no services } \\
\text { offered }\end{array}$ & $\begin{array}{l}\text { Poor; no laundry or } \\
\text { recreation areas } \\
\text { offered }\end{array}$ & $\begin{array}{l}\text { Limited; age - } \\
\text { mixed residents }\end{array}$ & $\begin{array}{l}\text { Average; private } \\
\text { entry with standard } \\
\text { locks }\end{array}$ & $\begin{array}{l}\text { Small pets with } \\
\text { deposit; visitors } \\
\text { daily }\end{array}$ \\
\hline 8. & $\begin{array}{l}\text { \$1,800 per month; } \\
\text { utilities; Medicare \& } \\
\text { Medicaid }\end{array}$ & $\begin{array}{l}\text { Small; } 1 \text { bedroom; } 1 \\
\text { bath; } 280 \text { sqft. }\end{array}$ & $\begin{array}{l}\text { Average; near } \\
\text { urban area }\end{array}$ & $\begin{array}{l}\text { Good; complete; on - } \\
\text { call physician \& } 24 \text { - } \\
\text { hr. RNs }\end{array}$ & $\begin{array}{l}\text { Good; } 3 \text { full meals; } \\
\text { housekeeping, } \\
\text { laundry, personal care }\end{array}$ & $\begin{array}{l}\text { Good; all seniors; } \\
\text { daily programs, } \\
\text { crafts }\end{array}$ & $\begin{array}{l}\text { Average; } \\
\text { receptionist at } \\
\text { building; low } \\
\text { security for } \\
\text { individual units }\end{array}$ & $\begin{array}{l}\text { Small pets with } \\
\text { deposit; visiting } \\
\text { hours }\end{array}$ \\
\hline
\end{tabular}




\begin{tabular}{|c|c|c|c|c|c|c|c|c|}
\hline & Rent & Size & Locale & Medical Services & $\begin{array}{l}\text { Non-Medical } \\
\text { Services }\end{array}$ & Social & Safety & Rules/Options \\
\hline 1. & $\begin{array}{l}\$ 1,875 \text { per } \\
\text { month; utilities; } \\
\text { No Medicaid or } \\
\text { Medicare }\end{array}$ & $\begin{array}{l}\text { Small; } 1 \\
\text { bedroom; } 1 \\
\text { bath; } 335 \text { sqft. }\end{array}$ & $\begin{array}{l}\text { Good; Near large } \\
\text { metro area }\end{array}$ & $\begin{array}{l}\text { Limited; RN during } \\
\text { day; } 24-\mathrm{hr} \text {. } \\
\text { personal care } \\
\text { assistants }\end{array}$ & $\begin{array}{l}\text { Excellent; laundry, } \\
\text { heavy housework; } 1 \\
\text { full \& } 2 \text { light meals }\end{array}$ & $\begin{array}{l}\text { Excellent; All } \\
\text { seniors; exercise } \\
\text { room; daily } \\
\text { programs }\end{array}$ & $\begin{array}{l}\text { Excellent; Reception desk } \\
\text { \& alarm at entry; private } \\
\text { systems for units }\end{array}$ & $\begin{array}{l}\text { No pets; visiting } \\
\text { hours }\end{array}$ \\
\hline 2. & $\begin{array}{l}\$ 800 \text { per moth, } \\
\text { utilities; Medicare } \\
\& \text { Medicaid } \\
\text { accepted }\end{array}$ & $\begin{array}{l}\text { Large; } 6 \\
\text { bedroom; } 2 \\
\text { baths; } 1500 \\
\text { sqft. }\end{array}$ & $\begin{array}{l}\text { Good; residential } \\
\text { area; near } \\
\text { shopping \& } \\
\text { recreation }\end{array}$ & $\begin{array}{l}\text { Good; visiting nurse; } \\
24 \mathrm{hr} \text {. emergency } \\
\text { call; live - in } \\
\text { assistant }\end{array}$ & $\begin{array}{l}\text { Very good; } 3 \text { full } \\
\text { meals; laundry \& } \\
\text { housekeeping }\end{array}$ & $\begin{array}{l}\text { Good; all seniors, } \\
\text { many with } \\
\text { disabilities; daily \& } \\
\text { weekly meetings } \\
\end{array}$ & $\begin{array}{l}\text { Good; electronic entry to } \\
\text { building and units }\end{array}$ & $\begin{array}{l}\text { No pets; visitors } \\
\text { cannot stay }\end{array}$ \\
\hline 3. & $\begin{array}{l}\text { \$1,030 per } \\
\text { month; utilities } \\
\text { included; No } \\
\text { Medicaid or } \\
\text { Medicare }\end{array}$ & $\begin{array}{l}\text { Average; } 2 \\
\text { bedrooms, } 1 \\
\text { bath; } 900 \text { sqft. }\end{array}$ & $\begin{array}{l}\text { Excellent; near } \\
\text { large metro area; } \\
\text { close to shopping } \\
\text { and recreation }\end{array}$ & $\begin{array}{l}\text { Limited; } 24-\mathrm{hr} \text {. } \\
\text { emergency call } \\
\text { system, weekly visit } \\
\text { by RN }\end{array}$ & $\begin{array}{l}\text { Very good; in - house } \\
\text { laundry facilities, } 1 \text { full } \\
\text { and } 2 \text { light meals }\end{array}$ & $\begin{array}{l}\text { Very good; All } \\
\text { seniors; daily } \\
\text { classes \& } \\
\text { programs; weekly } \\
\text { trips } \\
\end{array}$ & $\begin{array}{l}\text { Very good; security } \\
\text { entrance; each unit has } \\
\text { double locks }\end{array}$ & $\begin{array}{l}\text { Pets with a deposit; } \\
\text { visitors can stay } \\
\text { overnight }\end{array}$ \\
\hline 4. & $\begin{array}{l}\$ 4,152 \text { per } \\
\text { month; utilities; } \\
\text { Medicare \& } \\
\text { Medicaid } \\
\text { accepted }\end{array}$ & $\begin{array}{l}\text { Small; } 1 \\
\text { bedroom; } 1 \\
\text { bath; } 300 \text { sqft. }\end{array}$ & $\begin{array}{l}\text { Excellent; near } \\
\text { large metro area; } \\
\text { landscaped } \\
\text { grounds }\end{array}$ & $\begin{array}{l}\text { Excellent; complete, } \\
24-\text { hr. physician \& } \\
\text { RNs; acute care } \\
\text { facilities }\end{array}$ & $\begin{array}{l}\text { Excellent; all meals; } \\
\text { complete } \\
\text { housekeeping, } \\
\text { laundry, personal care }\end{array}$ & $\begin{array}{l}\text { Very good; all } \\
\text { seniors; full - time } \\
\text { activities director; } \\
\text { daily programs }\end{array}$ & $\begin{array}{l}\text { Good; electronic key } \\
\text { entry to building; low } \\
\text { security for units }\end{array}$ & $\begin{array}{l}\text { Pets under } 10 \text { lbs. } \\
\text { with deposit; } \\
\text { visitors can stay }\end{array}$ \\
\hline 5. & $\begin{array}{l}\text { \$1,200 per } \\
\text { month; utilities; } \\
\text { Medicare \& } \\
\text { Medicaid } \\
\text { accepted }\end{array}$ & $\begin{array}{l}\text { Small; } 1 \\
\text { bedroom; } 1 \\
\text { bath; } 300 \text { sqft. }\end{array}$ & $\begin{array}{l}\text { Average; near } \\
\text { urban area }\end{array}$ & $\begin{array}{l}\text { Good; } 24-\mathrm{hr} . \\
\text { physician \& RNs; } \\
\text { acute care facilities }\end{array}$ & $\begin{array}{l}\text { Good; all meals; } \\
\text { housekeeping; } \\
\text { laundry, personal care }\end{array}$ & $\begin{array}{l}\text { Good; all seniors; } \\
\text { part - time } \\
\text { activities director; } \\
\text { daily programs }\end{array}$ & $\begin{array}{l}\text { Average; receptionist at } \\
\text { building entry; low } \\
\text { security for units }\end{array}$ & $\begin{array}{l}\text { Mid - sized pet, no } \\
\text { deposit required; } \\
\text { visiting hours }\end{array}$ \\
\hline 6. & $\begin{array}{l}\text { \$795 per month; } \\
\text { utilities included; } \\
\text { No Medicaid or } \\
\text { Medicare }\end{array}$ & $\begin{array}{l}\text { Large; } 1 \\
\text { bedroom; } 1 \\
\text { bath; } 1200 \text { sqft. }\end{array}$ & $\begin{array}{l}\text { Excellent; near } \\
\text { suburban shopping } \\
\text { \& recreation area; } \\
\text { garden }\end{array}$ & $\begin{array}{l}\text { Poor; } 24-\mathrm{hr} \text {. } \\
\text { emergency call }\end{array}$ & $\begin{array}{l}\text { Average; coin laundry; } \\
\text { light breakfast }\end{array}$ & $\begin{array}{l}\text { Average; age - } \\
\text { mixed residents; } \\
\text { indoor pool; party } \\
\text { room, exercise } \\
\text { room }\end{array}$ & $\begin{array}{l}\text { Very good; electronic key } \\
\text { entry to building \& units }\end{array}$ & $\begin{array}{l}50 \mathrm{lb} \text {. pet with } \\
\text { deposit; daily } \\
\text { visitors allowed }\end{array}$ \\
\hline 7. & $\begin{array}{l}\$ 600 \text { per month; } \\
\text { no utilities; No } \\
\text { Medicaid or } \\
\text { Medicare }\end{array}$ & $\begin{array}{l}\text { Large; } 2 \\
\text { bedrooms; } 1 \\
\text { and one }- \text { half } \\
\text { bath; } 1220 \text { sqft. }\end{array}$ & $\begin{array}{l}\text { Average; near } \\
\text { downtown area; } \\
\text { close to business } \\
\text { district, hospitals }\end{array}$ & $\begin{array}{l}\text { No additional } \\
\text { services offered }\end{array}$ & $\begin{array}{l}\text { Good; indoor pool; } \\
\text { exercise \& recreation } \\
\text { rooms; coin laundry }\end{array}$ & $\begin{array}{l}\text { Poor; no planned } \\
\text { activities; mix of } \\
\text { age groups and } \\
\text { nationalities }\end{array}$ & $\begin{array}{l}\text { Average; private key- } \\
\text { lock entry to units }\end{array}$ & $\begin{array}{l}\text { Small pet with } \\
\text { deposit; visitors } \\
\text { allowed }\end{array}$ \\
\hline 8. & $\begin{array}{l}\text { \$340 per month; } \\
\text { no utilities; No } \\
\text { Medicaid or } \\
\text { Medicare }\end{array}$ & $\begin{array}{l}\text { Average; } 1 \\
\text { bedroom; } 1 \\
\text { bath; } 550 \text { sqft. }\end{array}$ & $\begin{array}{l}\text { Good; suburban, } \\
\text { residential area; on } \\
\text { bus line to } \\
\text { shopping }\end{array}$ & $\begin{array}{l}\text { Poor; no services } \\
\text { offered }\end{array}$ & $\begin{array}{l}\text { Poor; no laundry or } \\
\text { recreation areas } \\
\text { offered }\end{array}$ & $\begin{array}{l}\text { Limited; age - } \\
\text { mixed residents }\end{array}$ & $\begin{array}{l}\text { Average; private entry } \\
\text { with dead - bolt locks }\end{array}$ & $\begin{array}{l}1 \text { pet under } 10 \text { lbs.; } \\
\text { visitors can stay } \\
\text { overnight }\end{array}$ \\
\hline
\end{tabular}




\section{Appendix B}

We make many decisions every day. Below are several areas of decisions you may or may not have had to make.

1. For each of the following, please indicate how IMPORTANT you think each choice is, how EMOTIONALLY MEANINGFUL, INTELLECTUALLY DIFFICULT you think each choice is, and how RECENTLY you made each choice::

\begin{tabular}{|c|c|c|c|c|}
\hline & IMPORTANT & MEANINGFUL & DIFFICULT & RECENCY \\
\hline a place to live & $\boldsymbol{\nabla}$ & 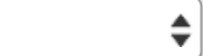 & $\boldsymbol{\nabla}$ & $\boldsymbol{\nabla}$ \\
\hline a school to attend & $\mathbf{v}$ & $\boldsymbol{\nabla}$ & $\mathbf{\nabla}$ & $\boldsymbol{\nabla}$ \\
\hline a car to buy & $\boldsymbol{\nabla}$ & $\boldsymbol{\nabla}$ & $\mathbf{v}$ & 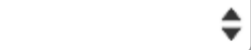 \\
\hline $\begin{array}{l}\text { a health insurance } \\
\text { plan }\end{array}$ & $\mathbf{v}$ & $\boldsymbol{\nabla}$ & $\boldsymbol{\nabla}$ & $\hat{\nabla}$ \\
\hline what to eat for lunch & $\boldsymbol{\nabla}$ & $\mathbf{v}$ & $\mathbf{v}$ & 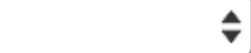 \\
\hline a dating partner & 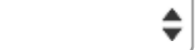 & $\mathbf{\nabla}$ & $\mathbf{\nabla}$ & $\boldsymbol{\nabla}$ \\
\hline whether to exercise & $\mathbf{v}$ & $\boldsymbol{\nabla}$ & $\boldsymbol{\nabla}$ & $\hat{\nabla}$ \\
\hline which computer to buy & $\boldsymbol{\nabla}$ & $\boldsymbol{\nabla}$ & $\mathbf{v}$ & $\boldsymbol{v}$ \\
\hline $\begin{array}{l}\text { which cancer treatment } \\
\text { to use }\end{array}$ & 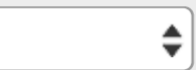 & $\boldsymbol{\nabla}$ & $\boldsymbol{\nabla}$ & $\boldsymbol{v}$ \\
\hline
\end{tabular}

